\title{
The Foundation and Development of Modern Teacher Training Systems
}

\author{
Mustafa ERGÜN*
}

Received: 22 October 2015

Accepted: 17 November 2015

\begin{abstract}
This article focuses on teaching profession in societies such as India, China, Egypt and Mesopotamia in ancient times. Besides, it focuses on teaching in religion schools. Protestant movement, which began in Germany in $1520 \mathrm{~s}$, revealed phenomenon of training teachers who were not from clergy. Such teacher training efforts initiated after the 1670s revealed two teacher training institutions called "Seminar" and "Normal" schools. The 18th century was a period in which the modern teacher education spread out in all countries. On the other hand, the formation of nation-states began. In the 19th century, teachers became away from the church, and after the salary given by the state, they separated from public's wishes and orientation and completely attached to the state. States, with completely taking inspection system from churches, began to provide "state education" to form a new human being (Bildung) and to use education as a tool for social integration and economic development. They get the most support from teachers they trained and gave salary. The 20th century was the period of planning and implementation of teacher education in higher education.
\end{abstract}

Keywords: Teachers, teacher training schools, teacher training, accreditation.

\section{Extended Abstract}

This paper focuses on the teaching activities in the religious education institutions. It begins firstly by discussing the teaching profession in civilizations like India, China, and Egypt-Mesopotamia in ancient times. It then examines the Protestant movement that started the 1520's in Germany, which paved the way for teaching religion proper in mother-tongues. Soon after, the Catholic Church began to widely spread primary school education with the help of several charitable foundations and donations. This helped training teachers who were not men of the clergy. Starting after the 1670s, such teaching efforts created two teacher training establishments named "Seminar" and "Normal". This process helped foster the regulation of school books and daily school life, education methods and principles, and the concepts of lesson planning.

The $18^{\text {th }}$ Century was a time when modernized teacher training became widespread in all nations and nation states began to form. The $19^{\text {th }}$ century was the century when teachers became totally reliant on the state, not listening to the wishes and directions of the public, after further stepping away from the church and being paid monthly by the state. To shape humans (bildung) and use education as a means for social integration and economic development, the states that fully adopted the supervision system from

\footnotetext{
* Prof. Dr., Afyon Kocatepe University, Afyonkarahisar, Turkey, ergun@aku.edu.tr
}

\section{Citation Information}

Ergün, M. (2016). Modern öğretmen yetiştirme sistemlerinin kurulması ve gelişmesi. Kuramsal Eğitimbilim Dergisi [Journal of Theoretical Educational Science], 9(3), 347-378. 
the church became "education states". The biggest support came from the teachers that they trained and put on monthly wage.

The $18^{\text {th }}$ century was a time when modernized teacher training became widespread in all nations. In the $19^{\text {th }}$ century, teachers became totally reliant on the state, for their monthly salaries and stepped further away from the church. To improve humanity (bildung) and use education as a means for social integration and economic development, states took over the supervision system from the church and became "education states". The biggest support came from the teachers that they trained and paid a monthly wage. The $20^{\text {th }}$ century was a time when teacher training was planned in the frame of higher education, and then put into practice. During the Weimar Republic in Germany (1920), teacher training efforts began in Academies. This was soon adopted in college education (hochschule) in the 1960s and towards the end of the century, Teacher Training Centers (Lehrerausbildungszentren) were created. In France, teacher training was given on undergraduate level after the1970s. England adopted teacher training in college education after the Second World War and was carried out it in the Institutes of Education in the 1980s. However, they changed the four-year undergraduate programs to colleges of education that offered bachelor's degree. After 1990, they have also worked with numerous establishments to provide proper standards and accreditation for many different teacher training systems. At the beginning of the 20th century in the United States, four-year teacher training colleges (normal school) were transformed into teacher colleges on a higher level. Between 1950 and 1970, all "normal schools" went through this transformation within the body of state universities, meaning that every single American normal school was upgraded in the mid- $20^{\text {th }}$ century from teacher schools to teacher colleges. In the 2000's, teacher standards were improved as well and thus qualified teachers were trained.

Purpose and Significance: The paper tries to explain how the teacher training systems were formed in modern Western states by examining the process in Germany, France, England, and USA. An intense debate is taking place about the nature and location of teacher training. An intense debate is taking place about the nature and location of teacher training. There is a longstanding and ongoing debate about the teacher's role in the constructivist teaching. The paper discusses the role of teacher in post-modern society and teacher's place in the postmodern education. This paper investigates the historical development of teacher training with the aim of identifying keys ideas that can improve teacher training at large.

Methods: This documentary research is a study of the history of education. It examines the Western roots of teacher training using theses and research paper as a basis. Important facts in the history of each nation were verified by checking with various sources. The web addresses of some of the used sources are also given. The purpose was to conduct a comparative study of the history of education. As communities with 
close contact to one another were studied, it was not difficult to comparatively follow the state of affairs.

Results: In ancient times, teachers may have taught for pleasure or money. But in the medieval era, cleric teachers were used as propaganda for religion and its teaching. After the Reformation, "normal schools", which trained teachers who were not members of the Church, began to open in succession. These schools escaped from the control of churches and found their way into the control of nation state. This was mainly because they emphasized non-religious lessons in their curriculum. Teacher training was adopted into the field of college education before the $20^{\text {th }}$ century, and after a short use of college/ institute/ academy formats, it was used in undergraduate and postgraduate levels.

Discussion and Conclusion: Even though these schools tried to reduce the control of the church and religious communities on teachers in Europe and America, they failed to completely break the impact of religious power on the teacher training schools. However, the shift of teacher training in the tertiary level completely blocked religious pressures on these schools. While holding examinations to select teachers is ancient practice, using a selection committee of clergy under religious control continued. Switching to examinations like tests, quizzes and exams prevented this. As ministers of education in nation states fully took on the inspection of schools and teachers, they helped teachers move away from religious control. Therefore, a shift from clergyman to educator and from nun to schoolmistress occurred. Universities have been considered the best teacher training institutions for over one hundred years. Because of all levels vocational training to be provided at tertiary level given of teacher education in universities is no longer discussed. The Department of Educational Sciences and academics do not only conduct research on learning problems and solutions for these problems, but also train teachers. In addition to teacher selection, qualifications for how teachers need to be trained are determined during the undergraduate study, and practices and institutions that train teachers are to be accredited in this regard. Another topic for future discussion will be evaluating the positive and negative effects caused by gradual changes in the teaching profession, specifically the shift from a male dominated to a female-dominated field. 


\title{
Modern Öğretmen Yetiştirme Sistemlerinin Kurulması ve Gelişmesi
}

\author{
Mustafa ERGÜN*
}

Makale Gönderme Tarihi: 22 Ekim 2015

Makale Kabul Tarihi: 17 Kasım 2015

\begin{abstract}
ÖZ: Bu makalede çok eski tarihlerde Hindistan, Çin, Mısır-Mezopotamya gibi toplumlarda öğretmenlik mesleği üzerinde durulduktan sonra dini eğitim kurumlarında öğretmenlik faaliyeti üzerinde durulmuştur. 1520'lerde Almanya'da başlayan Protestan hareketi, din adamı olmayan öğretmen yetiştirme olgusunu ortaya çıkarmıştır. 1670'lerden sonra başlayan bu tür öğretmen yetiştirme çabaları "Seminer" ve "Normal" okul adlı iki öğretmen yetiştirme kuruluşunu ortaya çıkarmıştır. 18.yüzyıl bir taraftan modern öğretmen yetiştirmenin bütün ülkelerde yaygınlaştığı bir taraftan da ulus devletlerin oluşmaya başladığı bir dönem olarak geçti. 19.yüzyıl ise öğretmenlerin iyice kiliseden uzaklaşıp, maaşlarının da devlet tarafından verilmesinden sonra, halkın istek ve yönlendirmelerinden çıkıp tamamen devlete bağlandığı bir dönem oldu. Teftiş sistemini de kiliseden tamamen alan devletler yeni bir insan oluşturmak (bildung), eğitimi toplumsal bütünleşme ve ekonomik kalkınmada bir araç olarak kullanmak için bir "eğitim devleti" haline geldiler. Burada en büyük desteği kendi yetiştirdikleri ve maaş verdikleri ögretmenlerden aldılar. 20.yüzyıl öğretmen yetiştirmenin yükseköğretim seviyesinde planlanması ve gerçekleştirilmesi dönemi oldu.
\end{abstract}

Anahtar kelimeler: Öğretmen, öğretmen okulu, öğretmen yetiştirme, akreditasyon.

19.yüzyll bütün dünyada herkese ilkögrretim yaptırma yüzyll idi, 20.yüzyll herkese ortä̈ğretim yaptırma yüzyılı oldu, 21.yüzyll ise herkese yüksekögrretim yaptırma yüzyll olacaktır.

\section{Öğretmenliğin Tarihsel Zemini}

Tarihin her döneminde, öğretmenler toplumların ve toplumsal kurumların kurulmasında önemli bir rol oynamışlardır. İnsan "eğitime muhtaç ve eğitilmeye en uygun" canlı türü olduğundan, ilk toplumlardan itibaren genel anlamıla kültürün öğretilmesinde aile ve yakın çevre kadar öğretmenler de görev almıştır.

Bu açıdan eski Hindistan'a baktı̆̆ımızda, MÖ 3000'ler öncesini işaret eden Vedik dönemde ve daha sonraki tarihlerde Veda adlı kitaplara dayalı bir öğretim vardı. Dünyanın en eski eserleri olarak bilinen ve 10 kitaptan oluşan Rig-Vedalar öğretilirken öğrenci-öğretmen ve okul kavramları ana hatlarıyla ortaya çıkmıştı. Vedaların yazıdan değil, bir öğretmenin dudaklarından öğrenilmesi gerekiyordu. Veda "mantra"larının doğru aksan ve tonlama ile öğrenilmesi, ağızdan öğrenmenin gereklerinden biri idi (Altekar,1948). Uzun süre yazılı öğretime karşı çıkılarak herkesin öğretmeninden sözel öğrenme yoluyla öğrenmesi şart koşulmuştu. Sözlü eğitim ve hatta sözlü-yazılı eğitim (yazdırma, not tutturma) zamanında öğrenci-öğretmen bağlllı̆̆ çok fazla idi ${ }^{1}$.

Hintliler eğitime başlamayı ikinci doğum (Dwija) gibi görüyorlard1; burada Vadalar veya savitri-stanza anne, öğretmen baba olarak görülüyordu (Scharfe,2002). Çocuk, fiziksel doğumdan sonra âdeta bir de ruhsal doğum yapıyordu. Öğretmen (dcdrya), öğrencinin içine daha sonra doğacak bir embriyo yerleştiriyordu. Öğretim,

\footnotetext{
* Prof. Dr., Afyon Kocatepe Üniversitesi, Afyonkarahisar, Türkiye, ergun@aku.edu.tr

${ }^{1}$ Batı toplumlarındaki yüksek okur-yazarlık oranı, hafıza eğitiminin önemini azalttı. Günümüzde öğretmenin dışında kitap ve internet kaynakları o kadar çok ki, bu bağlılık giderek azalıyor; uzaktan eğitim gelişiyor. Eskiden iki kutuplu (bi-polar) eğitim egemen idi, şimdi üç kutuplu (tri-polar) ve daha çok kutuplu olanlara geçiliyor.
} 
herkesin içinde var olan ateşi yakmaya, öğrenciye içindeki kendini buldurmaya çalışıyordu. Öğrenciler, öğretmenin evinde hizmet görüyorlar ve eğitim alıyorlardı. Öğretmen ve öğrenci birbirlerinin şemsiyesi olmalı, birbirlerini korumalı idiler. Öğretmene mutlak bir sayg1 ve sadakat de eski öğretim sisteminin temel özelliklerinden biri idi. Öğretmene itaat şartt1; "öğretmenin senin Tanrın olabilir" (acarya- devo bhava) deniyordu (Swami,1995). Dersten sonra öğrenciler öğretmenin ayaklarına elleriyle dokunarak çıkarlard1. Öğrenciler, kendileri ve öğretmenleri için sadaka topluyorlard1.

Hindistan'da öğretmenlere Guru veya Acharya deniyordu. Öğretmenlerin kullandıkları arazi, vergiden muaf idi. Öğretmenlik her toplumda olduğu gibi, Hindistan'da da saygın ve ilahi bir meslek idi. İnsanın üç gurusu vardı: anne, baba ve öğretmeni. Veda öğretmenlerine acaryd (doğru yola götüren) deniyordu. Prensler ve zengin çocukları için özel öğretmen evleri ve okullar yaptırılıyordu (Scharfe, 2002). Öğretmen, öğrencinin kapasitesini bilmek zorunda idi (Buda'nın kendisi ve Tamil grameri Nannul böyle diyordu). Öğretmen ön kısım, öğrenci arka kısımdır; bu ikisini birleştiren bilgidir ve aradaki bağlantıyı yapacak olan da öğretimdir. Nannul kitabında dört öğretmen tipi pek makbul görülmüyordu: metodu olmayan öğretmen, öğrencilerin ulaşamadığ 1 öğretmen, yarım eğitilmiş öğretmen ve bilgisini öğrencilere aktarmayan sahtekâr öğretmen (bilmek, alıcının aldığıdır, Nannul). Öğretmen bildiği bütün kutsal bilgileri saklamadan öğretmeli idi.

Çin, Kore, Japonya ve Güneydoğu Asya'nın yüzyıllardır değişmez öğretmenleri olan Konfüçyüs, Lao-Tzu ve Buda günümüzde de hala birer öğretmen simgesi olma özelliklerini korumaktadır. MÖ 6.yüzyılda yaşayan Konfüçyüs (551-479) ve Lao-Tzu (571-531), geniş Çin coğrafyasında yaşayan halkları ve sonra diğer doğu Asya halklarını yüksek bir ahlâk ve sıkı bir düzen içinde tutmayı başarmışlardır. Çeşitli karmaşa dönemlerinde bu halklar Konfüçyüs felsefesi/dini ile rahatlamışlar ve tekrar düzen kumuşlardır. 20.yüzyıla kadar doğu ülkelerinin temel eğitim felsefesi Konfüçyüs söylemleri ve eserleri üzerine kurulmuştur. Konfüçyüs öğretisi üzerine dört kitap ve Çin kültürü üzerine beş klasik eser eğitimin temel kaynakları idi (Lee, 2000). Konfüçyüs, öğretmenin görevinin bilgi yaratmak değil, gelenekleri aktarmak olduğunu söylüyordu (Starr,2012). Konfüçyüs ustalarından Han Yu (768-824) öğretmenin görevinin Konfüçyüs felsefesinin özünü aktarmak (duan Dao), bigi aktarmak (şou, ye) ve ince anlamları açıklamak (jie huo) olduğunu söylüyordu (Cai, 2002). Bin yıllık bir geçmişe sahip öğretmen okulları (şifan) halk için aynı zamanda bir rol model öğretmen yetiştiriyordu (Elman,2000). Öğretmen kendisi aynı zamanda bir örnek olmalıydı. Eğitimden zekilerin de aptalların da alacağı farklı seviyelerde dersler vardı.

Lao-Tzu'nun görüşleri Tao dini şekline getirilmiştir. Tao sonsuz huzura götüren bir yol, her şeye hayat veren bir güçtür. Evrendeki en küçük zerreden en büyük akla kadar her şey birbirine bağlıdır ve bu da Tao'dur. Bu iki bilgeye daha sonra Hindistan'dan gelen Buda'nın öğretisi de katılmış ve toplumdaki binlerce öğretmen tüm insanlara bu din-felsefe karışımı öğretileri öğretmekle vakit geçirmişlerdir. Budist manastır tipi eğitim Song hanedanı zamanında Konfüçyüs sisteminden etkilenmiş, ama 
Ming hanedanı zamanında o öğretiye paralel Budist kitaplar ortaya çıkmış ve Budist okullar açılmıştır (Ding, 2001; Travagnin, 2014).

Çin'de eğitim -Antik Yunanda ve Hindistan'da olduğu gibi- seçkin bir gruba veriliyor ve bu elitlerin oluşturduğu feodal sınıf toplumu yönetiyordu. Sui hanedanından başlayarak Çin'i yöneten hanedanlar devletin merkezi bürokratlarını seçmek için sürekli sınavlar düzenlemişlerdir. Soylu çocuklarını bu sınavlara hazırlamak için de Xia hanedanı zamanından itibaren okullar açılmıştır (Elman,2000). MS 360'da Qi devletinde Jixia Akademisi açılmıştı. 950'lerde Beyaz Geyik Grotto Akademisi, 1111 'de Donglin Akademisi kuruldu ve burada yüksek Çinli bürokratlar yetişti. 1178'de ulusal askeri akademi kuruldu. Bunların dışında özel ve halk okulları olarak yaygın bir okul sistemi vardı ve burada binlerce öğretmen çalışıyordu. Öğretmenlerin ana görevi, öğrencileri Konfüçyüs felsefesi ile yetiştirmek, sivil ve askeri seçme sınavlarına hazırlamaktı (Cong,2007). Çin yazısının bugün bile öğretilmesinin ne kadar zor olduğu düşünülürse, Çin'de öğretmenlerin eğitimdeki önemi daha iyi anlaşılır.

Dünyanın bir başka önemli uygarlığı olan Mısır'da matematik, astronomi ve tıp alanındaki gelişmelerin bir öğretim sistemi olmadan oluşması ve sürdürülmesi imkânsızdır. Kökleri MÖ 3000'li yıllara giden bu uygarlıkta kendine has bir yazı geliştirilmiş, hala yapımı açıklanamayan piramitler yapılmış, seçkin sanat eserleri ortaya konmuştur. Mısır'da gelişen bilim ve felsefe sistemlerinin Yunan bilim ve felsefesine kaynaklık ettiği, oradaki dini-mistik inançların da Ortadoğu dinlerine kaynaklık ettiği (burada Mezopotamya etkisi daha fazla gibi görünüyor) açıtır (James, 1954; Duncan, 2013). Dünyanın ilk kütüphanelerinin de burada açıldığı göz önüne alınırsa (Zulu, 2012), bu toplumda öğretmenlerin rolü daha iyi anlaşılır.

Mezopotamya'da Sümerler ve Akadlarda da oldukça örgün bir eğitim sistemi vard1. Okullarda okuma-yazma ve matematik öğretiliyordu (Kramer, 1963; Özgül, 2011, Sayıl1, 1991).

$\mathrm{Bu}$ arada eski öğretmenler söz konusu olduğunda Antik Yunan ve onun sokak ögretmenleri olan sofistler de unutulmamalıdır. Sokaklarda bazen gezerek bazen uygun bir yerde durarak veya oturarak çeşitli konularda ders yapan bu öğretmenler, eğitimin iki önemli kavramı olan öğretmen ve ders programlarının oluşmasında önemli roller oynamıştır. Platon'un eserlerinde bazı sofistler (Gorgias, Protagoras, Hippias, Euthidemos gibi) boş sözler söyleyen çıkarcı öğretmenler olarak nitelense de, bunlar demokrasinin, kavga etmeden tartışmanın, insanları sözle ikna etmenin önemli olduğunun örneklerini vermişlerdir (Kiriş-Yılmaz, 2012; Uçak, 2006).

\section{Okulların Kuruluşu ve Dini Eğitim Kurumlarında Öğretmenler}

Eğitimin üç önemli unsuru öğretmen, öğrenci ve okuldur. Bunlardan öğretmen ve öğrenci her zaman var olmuştur. Öğretimin yapıldığı okullar ise değişik formatlarda çeşitli zamanlarda hep var olmuştur. Bazen açık havada, bazen bir ağaç altında veya kapalı bir mekânda öğretmen ve öğrencilerin bir arada bir şeyler öğrendiğine kaynaklarda rastlamaktayız. Çin'de, Hint'te, Mısır'da, Mezopotamya'da bu şekilde okul 
örnekleri hep vard1. Antik Yunan'da Platon'un Akademia's1 ve Aristoteles'in Lyceum'u birer okul mekânı iken, çok sayıda Gymnasium'da da eğitim yapılıyordu (Aytaç, 2012).

Ortadoğu'da özellikle Hristiyanlık ve Müslümanlık kendi alt öğretilerini ve okullarını kurarken büyük dini liderlere ve öğretmenlere dayanmışlardır. İslâmiyette medreseler ilk kurulurken mutlaka belli âlimler ve öğretmenler için kuruluyor (Köymen, 1975) veya orada çalışan öğretmenler medreseye genelde adını veriyordu (Wüstenfeld, 1837; Ergün, 2014; Nuaymî, 1990). Öğretmenler verdikleri diplomalarda (icazet) kendi öğretmenleri silsilesini mutlaka yazıyorlardı (Ergün, 1996; Atay, 1981; Ayar, 2014).

\section{Modern Eğitim Sistemlerinin Kuruluşu}

Modern eğitim sistemleri, Avrupa Orta çağındaki okul sistemlerinin evriminden ortaya çıktı. 1520'lerde hümanist hareketin üniversitelerin ders programlarında reform mahiyetinde değişiklik yapması, ardından Almanya'da başlayan Protestan hareketin özünde ve sonraki mücadelesinde ortaya çıkan okullaşma ve herkese kendi ana dilinde dini, sanatları ve birtakım "real” şeyleri öğretmeye başlamasıyla çıkan eğitim hareketi, modern eğitim sistemlerine giden yolu açtı. Katolik kilisesinin bu harekete ancak kendi eğitim sistemini kurarak cevap vermesi, artık kilise okulları felsefesinden vazgeçilip yeni öğretmenler yetiştirerek, yeni yöntemler, yeni dersler, zaman çizelgesi vs ile eğitimde rekabet içinde bir yenileşme başlattı. Belediyeler, şehir yönetimleri, prenslikler ve devletler de eğitim işinde giderek daha aktif rol oynamaya başladılar. Eğitimin toplum kalkınmasında, bireyin ve devletin refahında olumlu rol oynadığı daha açık görülünce de, herkes eğitimin gücünden yararlanmak istedi ve özellikle kilise ve devlet arasında okulların ve öğretmenlerin paylaşılamadığı bir dönem başladı.

\section{Öğretmen Okullarının Kuruluşu}

Kiliseler arası savaşı başlatan Luther, 1524'te aynı zamanda bütün çocukların Hristiyan okullarında eğitilmesini de istiyordu (Cabanel \& Encrevé, 2006). Luther yeni bir eğitim sistemi kurulmasını ve hemen öğretmen yetiştirmeye başlanmasını istiyordu. İlköğretim Protestanlığın çocuğudur. İlkokulları Latin Okullarından ayırma şerefi de Comenius'undur. Anadilde öğretim, her şeyin zamanında ve kendi düzeninde öğretilmesi, her şeyin sırayla öğretilmesi, zorlama olmadan öğretilmesi, bir zamanda tek şey öğretilmesi, ders kitaplarının belli bir plana göre yapılması vs. Comenius'un eğitime getirdiği ilkeler idi.

Her ne kadar öğretimde reformu Protestanlar başlatsa da eğitimin modernleşmesindeki esas gelişmeleri Katolikler sağlamışlardır. Katolikler 1534'te Trento'da üç defa uzun toplantılar yaptı ve onlar da eğitim sistemlerinde reform yapma kararı aldılar. Trento Konsülü kızların ve kadınların eğitilmesine de önem verilmesini istiyordu. Kızlar için okul, önce Kuzey İtalya'da Azize Ursula adına 1535'te kurulan dernek ile yaygınlaştı. Ursuline okulları 17. ve 18.yüzyıllarda bir kız okulu modeli olarak yaygınlaştı. Nicolas Barré, Ursuline okullarının yetersiz kaldığını görünce 1666'da Soeurs de l'Enfant Jésus adlı bir dernek kurarak eğitim çalışmalarını sistemleştirdi. Lyonlu papaz Vincent de Paul (1581-1660), 1617'de Hayır Kızları (Filles de la charité) adlı bir dernek kurarak köylerdeki yoksul kızlar için okullar açmaya ve 
okullardaki öğretmen ve yöneticilerin görevlerini bir kurallar kitabıyla ("Règles particulières pour les maîtresses d'école...") belirlemeye başladi.

Katolik din adamlarının giriştiği ilkokul seviyesinde okul açma girişimleri çok çeşitli şekillerde devam etti. Üç papaz tarafından üç tip okul kuruldu: Jacques de Batencour, Charles Démia ve Jean-Baptiste de La Salle okulları (Fosseyeux, 1912).

J.de Batencour yoksullar için kendi papazlık bölgesinde okullar kurdu ve Latince öğretme deneyimlerini 1654'te bir kitapta anlattı. Batencour'un kitabı, Démia ve La Salle'in çalışmalarını etkileyen ve ilham veren bir deneme idi. Lyon Papazı Ch. Démia (1637-1689) yoksul çocukların eğitimi için önce 1666'da Saint Charles Kardeşler Cemaatini, sonra da 1667 'da Lyon'da okulunu kurdu ve bu okullar hizla yayıldı. Démia, din adamlarından farklı öğretmenleri yetiştirmek için de 1671'de "le Séminaire de Saint Charles" adlı bir kurum kurdu. Démia kız çocuklarının erkek çocuklarından daha fazla korunmaya ihtiyaç duyduğunu görüyordu. Démia 1687 'de kadın öğretmenler de yetiştirmeye başladı. 1678'de bir okulun ve bir sınıfın nasıl kurulacağına dair Règlements'i (Règlements pour les écoles de la ville et diocèse de Lyon) yazdi.

Aziz Jean-Baptiste de La Salle (1651-1719), 1679'da bu eğitim çalışmalarının sistemsiz şekilde gitmeyeceğine karar verdi ve 1684'te "Hristiyan Okullar Kardeşliği i" (Frères de la communauté des écoles chrétiennes) diye bir örgüt kurdu. 1688'de Paris'e gitti ve orada okullar kurdu. Ölümünden sonra Dernek (Enstitü) çeşitli fonlar sağlayarak okulların yaşatılması ve yenilerinin kurulmasını sağladı. 18.yy başlarında Lasallian okulları yayılmaya başladı. La Salle ülkedeki bütün okulları sürekli dolaşarak kontrol etmeye başladı. La Salle kurduğu derneğin çalışma ilkeleri ve bu okullardaki eğitim düzeni hakkında iki kitap yazdı: Règles Communes de l'Institut des Frères des Écoles Chrétiennes ve Conduite des Écoles Chrétiennes. Öğretmen yetiştirme için de tavsiyeler ve ilkeler yazdı. Öğretmen yetiştirerek, La Salle'in koyduğu kuralları dakik şekilde uygulayarak başarılı bir eğitim yaptılar (Parker,1912). La Salle, din adamı olmayan (laymen) profesyonel öğretmenler yetiştirmeye çalışt1. 1685'de Reims'de bir Öğretmen Okulu (Séminaire de Maîtres) kurdu. La Salle, kurduğu ve yakından teftiş ettiği okullar ağında dini bir eğitim verdi; ama okulu ibadethaneden, öğretmeni din adamından ayırdı. Öğretmenlerin din adamı olmamasında Protestanlarla etkili mücadele de rol oynamış olabilir. La Salle'a, hem öğretmen yetiştirme hem de öğretim yöntemi üzerine olan görüşlerinden dolayı 1950'de Papalık tarafindan "öğretmenlerin pîri" (patron de tous les éducateurs) unvanı verildi.

La Salle'a kadar ilköğretimde bütün öğrencilere birden ders yapılıyordu (birleştirilmiş sınıflar, enseignement simultané) (Seeley,1904). 16.yüzyıl kolejlerinde ve küçük okullarda bu yöntem yaygın idi. La Salle ilk defa aynı yaştaki ve aynı seviyedeki öğrencilerden bir sınıf oluşturarak, bu sınıfı bir öğretmenin eğitmesini sağladı. Burada öğrenciler seviyelerine göre zayıflar, ortalar ve iyiler diye gruplara ayrılıyor, belli bir yöntemle ders anlatılıyor, değerlendirme yapılabiliyordu ${ }^{1}$. Öğretmenlere iyi

\footnotetext{
${ }^{1}$ Bu sınıf düzeni 19.yüzyıldaki ilköğretim okullarında ve öğretmen yetiştirmeden de uzun uzun tartışıldı. Guizot ve Ferry'nin çıkardığı kanunlarla La Salle yöntemi da desteklendi.
} 
öğrencilerden asistan veriyordu ${ }^{1}$. Okullarda okuma, yazma, imlâ, aritmetik ve İlmihal öğretiliyordu. La Salle da -Port Royalcılar gibi-, "okumada başlangıçta Fransızca kitaplar kullanılmalıdır" diyordu. Ancak rahatlıkla Fransızca okuyabilenler Latince derslerine geçmelidir. Okumayı öğrenmeyenler de yazı öğretimine başlamamalı idi. La Salle okulları, bireysel eğitimi ön plana çıkardılar.

La Salle öğrencilerin ve öğretmenlerin birbiriyle konuşmalarından hoşlanmıyordu ve onların sessiz kodlarla anlaşmalarını tercih ediyordu. Bunun için geniş bir işaretler dili oluşturulmuştu. La Salle teknik ve mesleki eğitim alanında da girişimlerde bulundu. Saint Yon'da kurduğu kolejde Latince öğretmedi; gençlere ticari, sanayi ve idari alanlarda eğitim verdi (Compayré,1889). Teftiş sistemi bu okulların papazlar tarafından denetlenmesiyle ortaya çıktı.

Protestanlıktan sonra 16.yyda Alman topraklarında Katolikliği canlı tutmak ve kaybolan yerlerde tekrar canlandırmak için birçok şehirde Cizvit okulları kuruldu. Cizvit kolejleri Protestanların gimnazyumları gibi, üniversiteye öğrenci hazırlıyordu. Cizvitler, öğretmenin alan bilgisine değil, kişiliğine önem veriyorlard1. Cizvit kolejleri beş yıl idi ve her yıl bir öğretmen öğretim yapıyordu. Dominiken tarzında eğitim yapılan bu kurumlarda sıkı bir disiplin, sınavlar ve derecelenme vardı. Öğrenci ve öğretmenler yatılı bir sistemde, sıkı bir dini disiplin içinde aynı yerde kalıyorlardı. Eğitimin iki ilkesi vardı: disiplin ve onur. Askeri bir düzen içinde sert cezalandırmalar da yapıyorlard1. Bu Dernek, Seminar dedikleri eğitim kurumlarında da ilköğretim öğretmenleri yetiştiriyordu. Seminarlar da kolejlere bağlı kurumlardı. Ayrıca öğretmen okulu olarak "Normalschule"ler vard1.

17.yüzyılda bu dini derneklerin kurduğu ve kendi okulları için yetiştirdiği öğretmenler dışında, okul mezunu veya pedagojik niteliklere sahip öğretmen yoktu. Bazen o yerin papazı, defincisi, hatta terzi ve ayakkabıcısı bile asıl işlerinin yanı sıra öğretmenlik yapabiliyorlardı. Tek sınıfı okullarda öğretim malzemesi ve kitap yok, çocuk sayısı da çoktu; bazen değişik yaşlarda 100'den fazla çocuk bir sınıfa doluyordu. Okulun öğrettiği de tutturarak okuma, bazı duaları ezberleme, şarkı kitabından bazı şarkılar söyleme tarzında idi. Basit hesap bile birçok yerde yoktu. Okul sosyal disiplinleştirme (Sozialdisziplinierung) rolü oynuyordu. Öğretmenler eli sopalı idi. Öğretmen ücretleri düşük olduğu için kaliteli öğretmen bulunamıordu.

Genelde ilköğretim düzeyinde açılan Francke okulları için çıkarılan yönetmelikler (Schulordnung) ve özellikle Halle'de kurulan Seminarium præceptorum adlı ilköğretmen okulu Almanya'da bir model oldu (1695). Francke'nin Seminarium'unda uzun süre ders vermiş olan J. J. Hecker, 1748'de Berlin'de, Halle'de öğrendiği metotlarla öğretim yapılan 4 yıllık bir öğretmen okulu kurdu. Bu, 1753'de Kraliyet Enstitüsü haline getirildi ve okul müdürleri yetiştiren okul olarak bütün Almanya'ya model oldu. Daha sonra başka Alman şehirlerinde de benzer öğretmen okulları açıldı. 1747'de kurduğu Realschule'de çalışacak kaliteli öğretmen bulamayınca,

\footnotetext{
${ }^{1}$ La Salle'ın bu yöntemi de daha sonra İngiltere ve Amerika başta olmak üzere bütün dünyada uygulanan LancasterBell veya monitorial sistemini andırıordu.
} 
Kraldan kendi öğretmen okulunu kurma izni aldı ve 1753 'te Halle modelinde bir öğretmen okulu kurdu. 1753'te Realschule'ye bağlı olarak bir Köy Öğretmen Okulu (kurmärkische Landschullehrerseminar) kuruldu. Hecker'in Realschule adlı okulu ve özellikle Öğretmen Okulu tüm Almanya ve Avusturya'da doğrudan ve dolaylı etkiler yapt1.

1717'de Prusya'da 5-12 yaş arası çocuklara okul mecburiyeti kanununu çıkarıldı. Öğretim paralı olduğu için yoksul eyaletlerde bu yasanın uygulanması zor oldu. Buralarda terzi, dokumacı, demirci, marangoz gibi meslek adamlarının öğretmen olarak çalışabilecekleri (1722), papazların sınavsız öğretmen olarak çalışabilecekleri (1736) gibi kararlar alındı (Alexander, 1919). 1732 ve 1735 'de iki yeni öğretmen okulu daha kuruldu.

Almanya ve Fransa'daki bu gelişmelere paralel olarak Rusya'da da 1725 'te St.Petersburg Öğretmen Okulu (Pedagoji Enstitüsü) kuruluyordu.

Büyük Frederik (Friedrich der Große) Polonya topraklarını elde tutabilmek için burada okullar kurulmasını ve Alman öğretmenler atanması uygulamasını başlattı. Büyük Frederik önce 170 okul açtı; buralara öğretmen yetiştirmek için 1770'li yıllarda üç ilköğretmen okulu açtı. Gene de öğretmen açığı kapatılamayınca engelliaskerler öğretmen olarak çalıştırılmaya başlandı (Neugebauer,1985). Özellikle BerlinKurmark'taki öğretmen okulu (Das Kurmärkische Küster- und Schullehrerseminar) genel bir okul zorunluluğu uygulamasının başlatılmasına imkân verdi (Reyer, 2006). Bu siralarda gazi bir asker olan E. von Rochow da bir öğretmen okulu kurdu. Çok başarılı öğretmenler yetiştirdi (Meyer,2003). Rochow'a, “Prusya 'nın Pestalozzisi” denildi.

1770 ve hele 1800'den sonra ilköğretmen okulları (Elementarschullehrerausbildung) merkezileştirildi, programları ortaklaştırıldı ve çok sayıda açılmaya başlandı ama gene de Almanya'da 1830'larda öğretmenlerin yarısı öğretmen okulu mezunu değildi. Meslekten olmayan öğretmenler sadece okuma öğretiyor, yazma öğretmiyordu (o zamanın istatistiklerinde okurlarla yazarlar arasında büyük bir fark vard1). İlköğretimin gelişmesi doğrudan doğruya ilköğretmen okullarının kurulması ve gelişmesiyle doğru orantılı idi.

Avusturya'lı J.I. von Felbinger, Sagan'da bir vakıf ve buna bağlı olarak 1762'de bir okul kurdu. Burada Saganschen Lehrart diye yeni bir öğretim metodu geliştirdi. 1763 'te öğretimin içeriği ve yöntemleri üzerine belirli kuralların (norm) öğretildiği bir öğretmen okulu ("Normalschule”) kurdu. Bu öğretmen okulu modeli daha sonra birçok öğretmen okuluna örnek oldu. 1774'te Alman öğretmen okullarının (Normalschulwesen) genel müdürü oldu. 1778 Avusturya öğretmen okullarının hepsinin genel müdürü oldu. $\mathrm{Bu}$ arada birçok Alman şehrinde Normalschule adlı öğretmen okulları açıldı (Hüttner, 1982).

1770’lede Bavyera bölgesinde de örnek okullarla öğretmen yetiştirme önem kazandı. Bazı şehirlerde seminer tipi öğretmen yetiştirme kurumları (seminaristischen Lehrerbildung) açıldı. 1770'te Würzburger Schullehrerseminar, 1790'da Salzburger Lehrerseminar, 1802'de Bamberger Schullehrerseminar açıldı (Hüttner, 1982). O sıralarda Münchener Lehrerseminar önce hizmet içindeki öğretmenlere kurslar verdi, 
sonra halkokulu öğretmenlerini yetiştirmeye başladı. Amberg'de seminer, Innsbruck'ta Normal-Hauptschule olarak öğretmen okulları açıldı.

Fransa'da modern ilköğretmen okullarının iki yüzyılı aşkın bir geçmişi vardır. Fransız İhtilâli sonrasında 1794'te yapılan yeni eğitim sistemi kurma çalışmaları sirasında hazırlanan Lakanal Komitesi Raporu öğretmen okullarının öğretmenlerini ve lise öğretmenlerini yetiştirecek bir öğretmen okulu (école normale) kurulmasını önerdi. $\mathrm{Bu}$ projeyi gerçekleştirmek için bir yıl sonra öğrenciler toplandı. Ülkenin her tarafindan seçilen 1.400 öğrenci burada öğretmen olarak yetiştirilecekti. Dört aylık kurs sonunda yetiştirilecek öğretmenler kendi bölgelerinde Cumhuriyetçi öğretmenler yetiştirmek için eğitim merkezleri kuracaklard1. Okul 1795'te açıldı ama birçok nedenden dolayı başarısız oldu, dört ay sonra dağıldı (Compayré,1889; Barnard,1969).

Napolyon'un Üniversite (Eğitim Bakanllğı) yönetim sisteminde 1808'de yayınlanan talimatta, her akademi (eğitim bölgesi) ya kendi öğretmen okulunu (École Normale) kuracak ya da kendi kolej ve liselerinde ilkokul öğretmeni yetiştirmek için bir veya iki sınıf açacak ve öğretmen yetiştirecekti. Bu girişim de çalışmadı.

19.yüzyıl başlarında Alman ilköğretim sistemini etkileyen büyük güç Pestalozzi'dir. Onun yanında yetişmiş Zeller (1804), Königsberg'de bir öğretmen okulu, Karalene'de bir Protestan, Braunsberg'de bir Katolik öğretmen okulu kurdu; ülkeyi dolaşarak mevcut öğretmenlerle toplantılar yaptı, konferanslar verdi. Çoğu din adamı bir grup genci Ifertan'a Pestalozzi'nin yanına gönderdi. Bunlar daha sonra yurtsever, aydınlanmacı öğretmenler olarak Prusya ilköğretimini esastan değiştirdi. Kendilerini "halkın ĕgitimcisi" olarak kabul ettirdiler. Öğretmen okullarının müdürlüklerine Pestalozzici yurtsever eğitimciler getirildi. Bunlar sadece çocukları değil, halkı da eğitmeyi hedeflediler.

1806'da Almanya'da 11 öğretmen okulu vard1; 1836'da 44'e, 1872'de 64'e, 1902'de 137'ye (16'sı kız öğretmen okulu idi) çıkarılabildi (Ofenbach, 2006). Öğretmen okullarına bitirme sinavi, Prusya'da 1826, Bavyera ve Baden'de 1825, Saksonya'da 1836 yılında konuldu. Başlangıçta öğretmen okullarının öğretim süresi iki yıl idi, ama zamanla artarak altı yıla çıktı. Öğretmen olmak isteyen Halkokulu veya ortaokul öğrencileri altı yıllık bir eğitimden geçerek ilkokul öğretmeni olabiliyorlardı. Bunun ilk üç yılı hazırlık okulu (Präparandenanstalt), son üç yılı da öğretmen okulu (Lehrerseminar) idi. Okul öğrencilerini sınavla alıyor, bitirme sınavı ile mezun ediyordu.

1810 y1lında Strazburg, 1806'da da Koblenz Öğretmen Okulunu kurmuş olan (Ehret,1971), Almanya'da eğitim görmüş Aşağı-Ren valisi A.de Lezay-Marnésia'nın gayretiyle Alman seminerleri modelinde ilk Fransız öğretmen okulu kuruldu. Bu okul 4 y1l öğretim süreli idi, öğretim süresi sonra üçe indirildi. Buradan mezun olanlarla Yukar1-Ren'de bir bölüm daha açıldı. Restorasyon döneminde bir şey yapılmadı ama 1820 yılında Alsas'da iki öğretmen okulu daha açıldı: Moselle ve Meuse. Bu okullar o kadar başarılı oldu ki, Strazburg modeli tüm Fransa'ya örnek oldu. Paris’te ve diğer şehirlerde resmi ve dini cemaatlerin onlarca öğretmen okulu açıldı. 
Gerek ihtilâl sonras1 Cumhuriyetçiler gerekse 1806'da Napolyon eğitimi "cumhuriyetçi" veya devlete hizmet edecek militan ve memur yetiştirmek için etkili olarak kullanmak istediler. Öğretmen okulları esas işlevini Napolyon'un eğitim projelerini gerçekleştirmede gösterdi. Napolyon'un öğretmen okulları, Cizvit kolejleri örneğindeki gibi, üniformalı ve yatılı öğrencilere askeri bir disiplinle eğitim veriyorlard1.

1808'de kurulan Paris İlköğretmen Okulu, 1835-1840 arasında Victor Cousin'in müdürlüğünde büyük bir saygınlık kazandı. 1810'larda hiç izin verilemeyen öğrencilere, daha sonraki yıllarda kademe kademe haftada iki kere dışarı çıkma izni verilmeye başlandı. 1869'a kadar dini ibadete katılmak isteğe bağlı idi. 1845 yılında okula Yüksek Öğretmen Okulu (École Normale Supérieure) adı verildi. Öğretmen okulu öğrencileri ilk yılın sonunda bakalorya, ikinci yılın sonunda lisans alıyorlardı. Daha sonra lise veya kolejlerde öğretmenliğe başliyordu. Okulun en başarılı on öğrencisi okulda öğretim asistanı (répétiteur) olarak kalıyor ve yardımcı (agrégé) öğretim elemanı oluyordu.

Fransa'da okul savaşları (les luttes scolaires, öğretim hürriyeti) (1815-1875) döneminin ana karakteristikleri kız ve erkek öğretmen okullarının gelişmesi ve öğretmenliğin politik gücünün kullanılması (Donnermair, 2010) dönemi olarak da adlandırılabilir. Katolik kilisesinin toplumda ve yönetimde güç kazanma çabalarına karşı bir hareket olarak ortaya çıkan ve Fransa'nın yanı sıra İsviçre, Almanya, Belçika, Hollanda, İspanya, İngiltere, Macaristan ve Amerika Birleşik Devletleri gibi ülkelerde görülen kültür savaşı (Kulturkampf) içinde kiliselerin eğitimde gücü sınırlanmaya çalışıldı. İlkokulları ve öğretmenlerini kilisenin bağlarından kurtarmak için de özel çabalar gösterildi; ama I. Dünya savaşından önce Katoliklerin \%95'i, Protestanların \%90’1 kendi dini okullarına gidiyordu.

Fransız öğretmen yetiştirme çalışmalarını 1815-1830, 1830-1850 ve 1850-1870 yılları olarak üç döneme ayırmak mümkündür.

1815'te Eğitim Bakanı Carnot, Paris'te daha sonra öğretmen okuluna dönüşecek bir deneme okulu (école d'essai) veya bütün diğer öğretmen okullarına örnek olacak bir Öğretmen Okulu kurumaya çalıştı, ama başaramadı. İlk dönemde, 1816'da ilkokul öğretmenlerinin bir sertifika sahibi olması istendi. Üç tür ${ }^{1}$ olan bu sertifikaları Akademilerin başındaki rektörler sınav yaparak verecekti. Hristiyan Okullar Kardeşliği öğretmenleri bu kuraldan muaf idi.

1810-20 arasında Strasbourg, Heldefange ve Bar-le-Duc'a ek olarak 1828-29'da eğitim bölgelerinde açılan 11 öğretmen okulu ve Paris'te monitör usulünü esas alan iki öğretmen okulu; ayrıca yukarıdaki 14 öğretmen okuluna ek olarak 1833'e kadar 34 öğretmen okulu daha kurulmuştu. $\mathrm{Bu}$ okulların hepsi aynı yapı özelliklerini göstermiyordu, bir kolej içinde açılmış sınıflar şeklinde olanları da vardı. Öğretim süresi

\footnotetext{
1 Öğretmenlerin sınavları ve sınıflandırılmaları: İlkokul öğretmenleri için üç tür sertifika vardı: Temel sertifika (Brevet Elémentaire), Üstün sertifika (Brevet Supérieur) ve Özel sertifika (Certificat d'Aptitude Pédagogique). Özel sertifika yazı, elişleri, müzik, beden eğitimi, biçki-dikiş gibi alanlarda veriliyordu. Bu belgeler yedi kişilik bir sınav komisyonu tarafından yapılan seçim sonunda veriliyordu.
} 
genelde iki yıl idi; ama bir ve üç yıl olanlar da vardı. Çoğu laik idi, ama dini cemaatlerin elinde olanlar da vardı. Programlar da çok çeşitli idi, hepsinde dini ve ahlaki eğitim en başta yer alıyordu. Ders veren 2-3 derleme öğretmen vardı, stajların nasıl yapıldığı belli değildi. Okula giriş yaş1 18 ile 30-35 arasında değişiyordu.

19.yüzyılın ilk yarısında öğretmenler ailelerin verdikleri ücretlerle çalıştığı için, ne öğretecekleri konusunda din adamları kadar aileleri de dinliyorlardı. Ama öğretmenlik bir meslek haline gelince, artık aileleri dinlemez oldular. 1833 Guizot Kanunu ile standart ve kapsamlı bir müfredat belirleninceye kadar velilerle öğretmenler çocuklara öğretilecek konular konusunda çok çekiştiler. Daha sonra öğretmen ücretlerini devlet vermeye başlayınca sorun kısmen çözüldü. Devlet daha sonra 1880'lerde parasız öğretim, okula devam zorunluluğu ve göndermeyenleri cezalandırma sistemi getirdi. Giderek çocuk eğitiminde velilerin rolü azaldı, öğretmenlerin rolü artt1.

1830-1850 dönemi denilen ikinci dönemde; Guizot 1832'de Bakanlığa gelince ilk işi öğretmen okullarını incelemek ve onlara bir düzen vermek oldu. Çıkarılan Yasaya göre Fransa'nın 87 bölgesi (departement) ya bağımsız olarak ya da komşu yönetim bölgesi ile ortak birer ilkokul öğretmeni okulu kuracak veya açılmış olanı devam ettirecekti. Sadece 1833 'te 18 yeni öğretmen okulu açıldı, ertesi yıl 8 daha, 1835 'te 3 tane daha... Bu okulların mahalli yönetimlerle bağlarını yavaş yavaş kesildi ve merkezi hükümete bağladi ${ }^{1}$. Programlara bir düzen vermeye çalıştı, ama fen bilimleri açısından çok zayıf, dini ve ahlaki değerler açısından güçlü programlar yapıldı. Öğretim süresi iki yıl olarak sabitlendi. Okulun müdürleri Bakanlık tarafından atanmaya başlandı. 1835'de buralarda çalışacak öğretmen ve yönetici atamaları hakkında bir genelge daha yayınlandı. Öğrencilerin özellikler belirlendi. 1836'da 64 öğretmen okulu kurulmuş 11 tanesi de kurulmayı bekliyordu. 1840'ta 76 öğretmen okulunun 4'ü kiliseye ve 2'si Frères'lere ait idi.

1848 yılında kıta Avrupa'sının büyük kısmını kapsayan sosyalist ayaklanmalar meydana geldi. Bu olayların içinde her çalışan grubu örgütlenip haklarını aradığı gibi, öğretmenler de örgütlenerek toplantılar yaptılar. 1848'de kurulan ve ilk toplantısını yapan Genel Alman Öğretmen Dernekleri (Allgemeinen Deutschen Lehrervereins), okulların devlet denetiminde olması, parasız eğitim, öğretmenlere lojman ve yeterli maaş ödenmesi gibi konular konuşuldu (Skopp, 1982). Aynı yıl Eisenach'ta toplanan Alman Öğretmen Birliklerinin Kuruluş toplantısında anaokulundan liseye kadar devletin tek bir okul sistemi kurmasını talep ettiler (Herrlitz vd., 2009) ama 1848 devriminden sonra öğretmenlere tepki gösterildi, öğretmen okulları kırsal bölgelere sürüldü. Öğretmenler ciddi olarak suçlandı ve eğitim politikacıları "dinsizleşmiş insanlığı" yeniden eğitmek istediler (Jeismann,1987). 1848 devrimi insanların kilise ve mahalli kontrollerden çıkıp bir merkezi devletin vatandaşları olmak istemeleri, öğretmenlerin de statülerinin tanınması ve maaş garantileri gibi hususları ortaya çıkardı. Prusya Kralı IV. Friedrich Wilhelm, 1848 olaylarından öğretmen okulu öğretmen ve öğrencilerini de sorumlu tutuyordu.

${ }^{1} 1889$ tarihli yasa ile de öğretmen okulları tamamen devlete bağlandı ve tektipleşti. 
O zaman Prusya'da 37 öğretmen okulu vardı. Bunlar kırlarda kurulmuş, mezheplere ve cinsiyete göre farklı öğretmen yetiştiren yatılı okullard1. F. Stiehl başkanlığında bir grup ilköğretmen okullarını yeniden düzenlemek için toplandı. Stiehl, Evangelik öğretmen okulu, ilkokullar ve hazırlık okulları hakkında muhafazakâr ve devrim karşıtı bir eğitim politikası oluşturdu (Jeismann, 1977). İlk düzenlemeyi Evangelik Öğretmen Okullarındaki öğretim üzerine yaptı ve tek sinıflı okullarda öğretmenlerin vereceği derslere nasıl hazırlanacaklarını belirlemeye çalıştı. Çocuklar iyi bir Hristiyan ve yurtsever olarak eğitilmeli idi. Öğretmen okullarına bir hazırlık sınıfı konulmalı, burada sağlam bir din eğitimi verilmeli ve daha sonra bunlar bir seçme sınavına tabi tutulmalı idi. Öğretmen okullarında öğrenciler pazar günleri kilisedeki ayine katılacaklar, bütün dualarla 30 kilise şarkısını da öğrenecekti. Stiehl düzenlemeleri 1872'ye kadar geçerli oldu.

1850'li yıllardaki karışıklıkların ve sosyal olayların sorumluları arasında öğretmen okulu mezunları da gösterildi. Güya bu okullar gençliğe ahlaki eğitim verecek kişiler yetiştirmiyordu. 1850'li yıllarda öğretmen okullarının ahlâki değerleri sorgulandı. H. Carnot, J.B. Saint-Hilaire ve J. Simon gibi eğitimcilerin de katıldı̆̆ 1 komisyonda ilköğretim yasası görüşüldü. Burada Falloux, öğretmenler okulları hakkındaki suçlamaların ciddi olduğunu ve bu denemeleri devam ettirmemeye karar verdiklerini söylüyordu. Ancak 1850 yasası eğitim bölgelerindeki öğretmen okullarının devam ettirilmesi hükmünü getirdi. Ama bu Komisyonun etkili üyelerinden Papaz Dupanloup'un bu okulları çok kötü eleştiren sözleri ${ }^{1}$, bu okulların tarihinde yeni bir dönemi başlatıyordu.

Fransa'da kadın öğretmenlerin büyük bir çoğunluğu rahibe idi. Napolyon döneminde kız öğretmen okulu hazırlıklarına başlanması kararlaştırıldı. Mevcut öğretmenler birtakım belgelerle kontrol edilmeye çalışıldı. Kız öğretmen okullarının kuruluşunda da -erkeklerde olduğu gibi- bağımsız okullar kuruluncaya kadar bazı okullara ek bölüm veya sınıflar halinde öğretim yapıld1. 1831'de Bayan Sauvan bir taraftan Paris kız okullarında öğretmenlik yaparken bir yandan da kız öğretmenleri yetiştirmek için kurslar veriyordu. Ancak 1838 'de ilk Kız öğretmen okulu açılabildi. 1840'lı yıllarda 12 yerde daha bu tür kız öğretmen okulları açıldı. Belediyenin Ecole supérieure'u 1838 'de Kı Öğretmen Okuluna (l'Ecole normale d'institutrices) dönüştürüldü; böylece Paris’te erkekler ve kızlar için iki öğretmen okulu kurulmuş oldu. Gard'da (Nimes) Protestanlar bir kız öğretmen okulu açmışlar, 1840'larda da Bakanlık Katolik ve Protestan kıların karma okutacağı bir kı öğretmen okulunu önceliğe almışt1, başaramadı.

1850 Kanunu öğretmen okullarını kapatmadı ama onları yıkacak mekanizmaları yarattı. Birçok yerde Genel Konsey’ler, bakanlık kararları ve öğrencilerin dağılması bu okulları âdeta yok etti. Kanun rahibelerin yönetimindeki öğretmen yetiştirme sınıflarını kapatmadı: 1850'de 21 olan bu tür siniflar 1879'da 50'ye çıktı. Ama bu okullara ilk

\footnotetext{
1 “Les écoles normales, si dangereuses, si puissantes pour le mal et qui ont si déplorablement dénaturé le caractère et la mission des instituteurs, sont supprimées." (Öğretmen okulları o kadar tehlikeli ve öğretmen karakter ve görevini o kadar bozan şeytanın emrindeki kurumlardır ki, hemen kapatılmalıdır)
} 
tepkiler geçtikten sonra 1860'l1 yıllarda beş yerde daha öğretmen okulu açıldı. Program dini derslerle dolduruldu. Okullar dini ögretmen okullart haline geldi. Öğretimde ve kontrolde papazların rolü çok artmıştı. Fransa'da 1850 hükümetin şüphe ile baktığ 1 öğretmen okulları Üçüncü Cumhuriyet döneminde Duruy bakanlığında tekrar gelişti. Duruy (1863-1869) dönemi öğretmen okulları açısından tamir dönemidir. Duruy bakanlığı döneminde bu okullarla sürekli ilgilendi. 1865 'te müzik dersi zorunlu hale getirildi, tarım dersi önem kazandı ve tarım öğretmenleri atandı. 1866'da okulların yeniden yapılandırıldığı ve 1851 kalıbının değiştirildiği görülüyor. Programlara resim, geometri, modern diller, 1867'de Fransa tarih ve coğrafyası eklendi. 1865'deki mesleki (spécial) ortaöğretim programının değişmesi ilkokullara yeni dersler eklemişti, dolayısıyla yeni öğretmenleri bu derslere da hazırlamak gerekti. Programlarda önemli değişiklikler yapıldı. Okula başlama yaşı 18'den 16'ya indirildi. Öğrenci kabul şartları ayrintılı olarak belirlendi.

Alman ruhunun uyanışında ve Alman birliğinin sağlanmasında Halkokulu öğretmenleri önemli rol oynadılar. Sadece çocukları değil, Alman halkını da eğittiler. Öğretmen Heinrich Julius Bruns'un (1746-1794) mezar taşında sadece $O$ bir ögretmendi (Er war ein Lehrer) yazar. Alman öğretmenlerinin ilkokullarda çocuklara kazandırdığ1 disiplin ve göreve bağlılık ahlâkı, Prusya'yı Fransız ve Avusturyalılara karşı galip getirmişti. Avusturya'ya karşı yapılan Königgrätz savaşını (1866) Prusya ilkokulları kazanmıştı. Bu efsane 50 yıl devam etti.

Almanya'da ilkokul öğretmenleri bir yandan öğretmen okullarında yetiştiriliyor, bir yandan da sınavla seçiliyordu. 1826'da başlayan bu sınavlar 1872, 1901 ve 1928'de yeniden düzenlendi ve 1938 'de tüm Almanya çapında yapılmaya başlandı (Bettermenn ve Goessl,1963).

O zamanlar meslek eğitimine "l'enseignement spécial" deniyordu. Mesleki eğitimi de Hristiyan Kardeşler devletten daha iyi yapıyordu. Duruy, özel mesleki eğitim öğretmenleri yetiştirmek için 1866'da Cluny'de bir Ecole normale de l'enseignement secondaire spécial açt ${ }^{1}$. Burası çeşitli okullara meslek ve sanat öğretmeni yetiştirmeye başladı.

$\mathrm{Bu}$ arada cemaatler de kendi öğretmen okullarını kurmuştu. Devletin öğretmen okullarından mezun olanlar dışında, cemaat öğretmenleri belediyelerin bulduğu laik öğretmenlerden (lay teacher) daha iyi öğretim yapıyordu. Devlet cemaat okullarında öğretmenlik yapanların resmi sinavlara girerek belge (brevet) alması zorunluluğunu getirmişti. 1870'de beş binden fazla rahibe öğretmenlik belgesi almıştı (Curtis, 1994).

Öğretmenliğin meslek haline gelmesinde en büyük rolü devlet oynadı. Resmi öğretmen okulları (1863'te sistemdeki öğretmenlerin yarısı öğretmen okulu mezunu idi), öğretmenliğin belgeye bağlanması, bu tür öğretmen sayısının artması ve okul içi faaliyetlerin berraklaşması bu süreç içinde oldu. Kontrol hem kilise hem de devlet

\footnotetext{
1 1891'de öğretmen okulu kapandı ve orta öğretmen okulu (Ecole primaire supérieure) olarak çalışmaya başladı. 1901'de Ecole nationale supérieure d'Arts et Métiers oldu.
} 
tarafindan yapılıyordu. Ama daha sonra papazların okullara girişi yasaklandı, programlar laikleştirildi.

Fransa'da 1867 Yasası 500 nüfustan fazla olan yerleşim yerlerinin ayrı kız okulları açmasını öngörüyordu, ama bu okullarda görev yapacak laik kadın öğretmenler (instructrices) yoktu. Dolayısıyla öğretmenlik rahibelere kalıyordu, laik kadın öğretmenler bile rahibeler gibi giyiniyordu (Harrigan, 2001). 1862'de resmi ve laik kadın mesleki öğretiminin başlaması çalışmaları başladı 1879 Bert Kanunu, her bölgede bir kız öğretmen okulu (école normale d'institutrice) mecburiyeti getirdi. Rahibelikten öğretmenliğe bir evrim gerçekleşti. Bazı dini grupların kurup yüzlerce öğretmen yetiştirdiği kurumlar öğretmen okulu olarak kabul edilmiyordu (Rogers, 2005).

1879'da laik kadın öğretmenler yetiştirmek için kanun çıkartıldı; 1872'de kadınlar için sadece dokuz öğretmen okulu vard1; bu say1 1882'de 41'e, 1887'de 81'e çıktı. Sée Kanununda kız öğretmen okullarına öğretmen yetiştirecek bir École normale supérieure kurulması hükmü de vardı. Jules Ferry 1880'de Fontenay-aux-Roses'da kızlar için bir yüksek öğretmen okulu (Écoles normales supérieures de l'enseignement primaire) kurmuştu, Sée de 1881'de Sèvres'de Kız Yüksek Öğretmen Okulu kurdu. Fontenay Yüksek Öğretmen Okulu, kız öğretmen okullarına öğretmen yetiştiriyordu. 1881'de kurulan Sèvres Yüksek Öğretmen Okulu da kız ortaöğretim okullarına öğretmen yetiştirecekti. Kadınların ev kadınlığından daha yüksek mevkilere yükselmesinde de kadın öğretmenler yetiştiren Sèvres Öğretmen Okulu önemli rol oynadi.

Anaokullarında İngiliz modeli uygulayan Fransızlardan M. Carpentier, Bakanlık tarafından Anaokulu Öğretmen Okulunu kurmakla görevlendirildi ve okul 1851'de Carpentier yönetiminde kuruldu.

Fransa'da öğretmen yetiştirmede 1870-1884 arası farklı bir dönemdir. 1878 kanunu erkek ve kız öğretmen okullarını Fransa geneline yaygınlaştırma çalışmalarını başlattı. 1879'da Ferry zorunlu, parasız ve laik ilköğretimi gerçekleştirmeye başladı. Bu çalışmalar içinde de en önemli yeri öğretmen okulları aldı. Öğrencilerin durumu iyileştirildi, vicdan hürriyeti sağlandı; zihniyet ve kişilik kalitesi artırılmaya çalışıldı. Öğretmenler sertifikalandırılarak yönetime bir ciddiyet getirildi. 1881'de Öğretmen Okulu programları vatandaşlık eğitimi, el işleri, ev ekonomisi gibi dersler konularak yeniden düzenlendi. Dini eğitim yasaklanmadı, ama seçmeli olarak okulların dışına alındı. Okula giriş yaşı $15^{\prime}$ 'e indirildi. Ferry politikasında ilkokul öğretmenleri Cumhuriyetin siyah süvarileri idiler.

1882 ve 1886 yasaları öğretmen yetiştirme işini cemaatlerden tamamen aldı. 1886 Goblet Kanunu ile resmi okullardaki dini öğretmenler uzaklaştırdı; öğretmenler, öğretmen okullarından alınacaktı. 1886'da rahibe kadın öğretmenlere yeni görev verilmemesi emredildi. Başlangıçta dini cemaatlerin elinde olan kadın öğretmen yetiştirme işi giderek onlardan alındı ve laik güçlere verildi (Gemie, 1995).

1889 yllında öğretmenlik resmi bir meslek hâline geldi. 1880’lerde ilkokul öğretmenlerinin statü ve ücretleri belirlendi. 1889 kanunu tüm ilkokul öğretmenlerinin 
ücretlerinin devlet tarafından ödenmesi hükmünü getirdi. Bütçeye bunun için büyük para kondu.

Fransız eğitim sisteminin önemli özelliklerinden biri öğretmenlerin otoritesidir. Öğretmenler hem sosyal ve politik değişmelerde hem de okul ve sınıf yönetiminde son derece etkili olmuşlardır ve olmaya da devam etmektedirler.

Almanya'da mezhep savaşları çok kızışınca, din görevlileri kendileri yetişkinlerle ilgilenmeye ve okulları din adamı olmayan öğretmenlere bırakmaya başladılar (Wriedt, 2008). Zaten dini gruplar da (Kardeşlerden Cizvitlere ve Francke'ye kadar) kendi öğretmen okullarını kurarak din adamı olmayan öğretmenler yetiştirmeye başladılar. Burada dindarlığın yanında, öğreteceği derslerin alan bilgisi ve öğretim metodu ve didaktiği açısından da yetiştirme önemli hale gelmeye başladı.

Almanya'da 19. yüzyılda gelişen Lehrerseminare tipi okullar 1918'de kapatıldı. Kapatılmadan önce, 1914'te Prusya'da 186 resmi erkek öğretmen okulu (119 Evangelik, 63 Katolik, 4 ortak) ve 45 resmi, özel ve şehirlere ait kız öğretmen okulu vard1 (Bettermenn \& Goessl, 1963). 1919'da 217 öğretmen hazırlık kuruluşu ve 191 öğretmen okulu vard1 (Ofenbach, 2006).

1848-49 devriminden sonra ilkokul öğretmenlerinin de üniversitelerde yetiştirilmesi istendi ama bu ancak Weimar Cumhuriyeti zamanında mümkün olabildi. 1920'de herkes için temel dört yıllık eğitim kanunu çıkartılırken bütün ilkokul öğretmenlerinin Abitur sahibi olması da şart koşuldu. İlkokul öğretmenleri yükseköğretim düzeyindeki “Pädagogische Akademien"lerde veya üniversitelerde yetişecekti. Eduard Spranger'in Bildnerhochscule modelinde (1920-70) (Gaus \& Drieschner, 2010), 1926'da Preußen Pädagogische Akademien kuruldu. Burası lise mezunlarını alacak, okullar artık kırsal kesimlerde kurulmayacak ve yatılı olmayacaktı (Blömeke, 2009). 1930'a kadar 15 akademi kuruldu. Bavyera ve Württemberg hala eski öğretmen okulu modelini (Seminarausbildung) koruyordu. Seminarlar kırsaldaki küçük kasabalarda olmasına karşılık, akademiler üniversitesi olan büyük şehirlerde idi. Buralara Abitur diploması olanlar giriyordu. Seminer öğrencileri yatılı idi, akademi öğrencileri gündüzlü üniversite öğrencileri idi ancak dünya ekonomik krizi dolayısıyla akademilerdeki öğrenci sayısı pek artmad1. 1932'de bu akademilerin sekizi kapand1 (Ofenbach, 2006). Mezunlar ilkokullarda iş bulamad1. Eskiden sadece gimnazyum öğretmenleri devlet sınavıyla seçilirken, akademilerin kurulmasından sonra halkokulu öğretmenlerinden de hem alan bilgisi hem pedagoji alanında devlet sınavına girmeleri istendi.

1931'de öğrencilerin \%40.7'si köylerde idi. Halkokulu öğretmenlerinin 2/3'ü öğretmen okulu mezunu idi. Bunlar kendi köylerinden geliyor, sekiz yıllık bir Halkokulu eğitimi alıyor ve geri köylerinde öğretmen oluyordu'. 1933'de Pedagoji Akademileri Hochschulen für Lehrerbildung oldu. 1945’ten sonra eski şekle geri

\footnotetext{
${ }^{1}$ (...kamen selbst aus dem Dorf, hatten lediglich eine achtjährige Volksschulzeit als Vorbildung und sollten wieder auf dem Dorfe tätig werden (Stahl,1988:22).
} 
dönüldü. 1945'ten sonra Hamburg bütün öğretmenleri üniversitede yetiştiriyordu, Baden-Württemberg seminar tipinde devam ediyordu.

Pedagoji akademileri 60'lı yılların ortalarından itibaren Pädagogische Hochschulelere dönüşmeye başladı. Hessen'de 1966, Bavyera'da 1970, Aşağ 1 Saksonya'da 1978, Nordrhein-Westfalen'de 1972 veya 1980, Rheinland-Pfalz ve Schleswig-Holstein'de 1990 başlarında bu kurumlar üniversiteler bünyesinde kuruldu. Sadece Baden-Württemberg'de üniversiteden bağımsız okul olarak çalışmaya devam etti (Blömeke, 2009).

Daha sonraki süreçte alan uzmanlıkları (öğretmenlikleri) ortaya çıktı. 1980'lerde Pedagoji yüksekokulları üniversitelere bağlanmaya başladı. 1998'de Yüksekokul Rektörler Konferansı (HRH), öğretmen eğitiminin yeniden yapılandırılması hakkında tavsiyeler yayınladı. Disiplinlerarası alan eğitimi merkezleri oluşturulmasını istedi. Kültür bakanları konferansı (KMK) da aynı yıl öğretmen eğitimi hakkında bir Komisyon kurdu. Komisyon üniversitelerdeki öğretmen ön eğitimi için Zentren für Lehrerbildung und Schulforschung'lar kurulmasını istedi. Yani öğretmen yetiştirmenin, fakültelerden bu merkezlere kaydırılmasını istedi. Zaten 1998'de Brandenburg, Hessen, Niedersachsen, Nordrhein-Westfalen ve Sachsen'de Öğretmen Yetiştirme Merkezleri (Lehrerausbildungzentren) vardı (Wilke, 2005). Daha sonra da birçok yerde öğretmen yetiştirme ve okul araştırmaları merkezleri kuruldu. Şu anda 60’tan fazla üniversitede öğretmen yetiştirme birimi var. Bunların 50 kadarı Zentrum für Lehrerbildung adını taşıyor.

$\mathrm{Bu}$ merkezler öğretmen yetiştirmeyi bütün unsurlarıyla (alan bilgisi, alan eğitimi, eğitim bilimleri, okul pedagojisi, eğitim psikolojisi vs) beraber yeniden ele alıp birleştirmeye çalışıyor. Eski Pädagogische Hochschuleler yerine, bilimsel araştırma da eklenerek bu merkezler kurulmuş. Yeni kurulan Eğitim Araştırmaları ve Öğretmen Eğitimi Akademisi, şu üç görevi yapıyor: a) öğretmen eğitiminde standartlar koyma, b) eğitim bilimlerini yapılandırarak öğretilmesi gereken alan bilgilerini belirleyip bunların nasıl öğretileceğini tespit etme, c) öğretmen yetiştirme programlarının (Lehramtsstudiengänge) öğretmenlik mesleği ile ilgili olmasını tasarımlamak.

1958 'de Fransa'da 150 ilköğretmen okulu (Écoles Normales Primaires) ve lise öğretmenliği için de erkekler ve kılar için birer tane Ecoles Normales Supérieures vardı (Koch,1989). 1960-70'lerde öğrenci sayıları birdenbire artınca Eğitim Bakanlığ1 bakaloryası olan kişileri bile öğretmen olarak atamıştı; on binlerce kişi o zaman öğretmen olarak işe başladı (hizmetiçi kurslarla yetiştirilmeye çalışıldı) (Prost, 1981). 1951-1964 arasında ilkokul öğretmeni olanların \%60'1 bu şekilde sisteme girdi (Prost, 1968).

1970'li yıllarda öğretmen yetiştirme sisteminde köklü reformlar yapıldı (Lewis, 1985). 1972'de bakalorya sınavını kazananlar öğretmen okullarında iki yıl daha öğrenim görerek öğretmen olmaya başladılar (Lewis, 1985). Öğretim süresi 1979'da üç yıla çıkartıldı ve öğretmen okulları o çevredeki üniversitelere bağlandılar. Son yirmi yılda öğretmen yetiştirmede öğretim süresi uzatıldı, kalite yükseltildi. İlkokul öğretmenliği 
için en az dört y1llık yükseköğretim, lise öğretmenliği için de lisans üzerine bir yıl teorik, bir yıl da uygulama getirildi ("consécutive" approach).

Kıta Avrupası'ndaki bu gelişmelerin yanı sıra İngiltere ve Amerika Birleşik Devletleri'ndeki gelişme biraz daha geriden ve farklı biçimlerde ortaya çıktı.

İngiltere'de öğretmen eğitimi büyük ölçüde devletin ilk ve ortaöğretimi kurma ve yaygınlaştırma politikasıyla beraber gider (Robinson, 2006). Burada hem okullardaki öğretmen ihtiyacının karşılanması hem de öğretmenlere verilecek maaş ve diğer haklar gelişmeleri etkilemiştir.

Önceleri soylu ve burjuva çocukları Oxbridge mezunu öğretmenler tarafindan eğitiliyordu ama 1805 'ten itibaren alt tabaka çocukları için de ilköğretim okulları açılmaya başlanınca, onlar için 1820-30 ve 40'lı yıllarda dini mezheplere dayalı bir öğretmen okulları ağı kuruldu. A. Bell ve J. Lancaster, okuldaki üst sınıf öğrencilerinden yardımcı öğretici olarak yararlanma (Hindistan'da eskiden beri uygulanan sistem) şeklindeki 'monitorial system'i bir öğretmen yetiştirme olarak uygulamaya başladılar ${ }^{1}$.

1837 y1lında D. Stow ve Kay-Shuttleworth, 'monitorial system'de bir reform yaparak Glasgow Öğretmen Okulunda öğrenci-öğretmen modelini uygulamaya başladılar (Jeong, 2009). 1840'lı y1llardan itibaren öğretmenlerin akademik ve mesleki kalite standartları artmaya başladı. Öğrenci seçiminden öğretime kurallar kondu. 1846'de The College of Preceptors kuruldu ve devlet öğretmen yetiştirme işine katılmaya başladı. Programlar ve teftiş sistemi vasıtasıyla bir birliktelik sağlanmaya çalışıldı. Ama gene de İngiltere'de çırak öğrencilerden öğretmen olarak yararlanmak (pupil-teacher system) $)^{2}$ geleneği uzun bir süre devam etti (Robinson, 2003).

1870 İlköğretim Kanunu birçok öğretmen ihtiyacı ortaya çıkardı ve sınavlarla birçok öğretmen alındı. 1880'lerden itibaren bu sistem modernleştirilmeye çalışıldı. Öğretmenlerin üniversitelerde veya üniversiteler ile iş birliği içinde yetiştirilmesi çalışmaları başladı. 1890'de İngiltere'deki 43 yatılı (residential) öğretmen okulunun sadece 8 tanesi dinî cemaatlerin kontrolünde değildi (Jeong, 2009). 1890'dan itibaren mahalli okul komiteleri mahalli üniversitelerle iş birliği yaparak, hükümet denetiminde gündüzlü öğretmen okulları (day training colleges) kurmaya başladılar. Bu öğretmen okulları zamanla üniversitelerin eğitim bölümlerine dönüştü. Burada mesleki eğitim ile akademik eğitim dengesi uzun süre kurulamadı (Dent, 1977).

20.yüzyıl başlarında belediyeler ve mahalli yönetimler öğretmen yetiştirme işinde çok daha etkin olarak rol almaya başladılar. Belediyeler öğretmen okulları açmaya başladılar. Öğretmen seçiminde akademisyenlerle eğitim kurulları ortak komisyonlar (Joint Board) kurarak çalışmaya başladı. 20.yüzyıl başlarında öğrenci-

\footnotetext{
1 "Monitorial system”, ilköğretim seviyesinde öğrencilerin aşağı yukarı onar kişilik gruplara ayrılarak her grubun başına başarılı son sınıf öğrencilerinden birer etütçü (monitor) tayin ederek öğretmen gözetim ve denetiminde çalışmalarını sağlamaktır. Bell'in Hindistan deneyimleri yayınlanınca, Lancaster buradaki öğrenci-öğretmenlere monitor adını vererek onları özel olarak eğitti (Kaestle, 1973).

2 Öğrenci ögretmenler bir okulda beş yıl çırak tarzında yetiştiriliyor, sonra Queen’s Scholarships sınavına alınıyor, kazananlar ögretmen okuluna devam ediyor, kazanamayanlar ise yardımcı öğretmen olarak çalışıyordu. Bu sınavlar 1863 'te kaldirıldı.
} 
öğretmen sistemi kaldırıldı ama üniversitelerin yanı sıra öğretmen okulu temelli yetiştirme 1980 sonlarına kadar devam etti. Yaklaşık 40.000 öğretmen açığını kapatmak için özellikle 1944-1951 arasında acil (hılı) öğretmen yetiştirme sistemlerinde (emergency training college) birçok öğretmen yetiştirildi. 1944 McNair Raporu, üniversitelerde eğitim enstitüsü veya öğretmen okulu kurulmasını öneriyordu. Bunun için Area Training Organisation (ATO) tavsiyelerine göre 1980'e kadar Eğitim Enstitülerinde (Institute of Education) öğretmen yetiştirildi.

1960'larda üniversitelerde üç yıllık öğretmen yetiştirme programları uygulanmaya başladı, 1964 'ten itibaren dört yıllık programlar da çıtı. Dört yıllık program uygulayanlar eğitim fakültesine (colleges of education) dönüştü ve 1968'de bazı üniversiteler lisans diploması vermeye başladılar. Bundan sonra öğretmen yetiştirme büyük ölçüde hükümet kontrolünde yapılmaya başlandı. 1970'li yıllarda lisans-mesleki eğitimin birleşik verildiği programlarla lisanstan sonra mesleki eğitim verilmesi (consecutive versus concurrent) modelleri tartışıld1 (The James Report). 197482 arasında hükümet öğretmen yetiştirme sistemini yeniden düzenledi (Cortis, 1985), bazı kapatmalar ve birleştirmeler yaptı.

Lisans mezunlarına bir yıllık öğretmenlik meslek bilgisi kursları PGCE (Postgraduate Certificate in Education) 1950'li y1llardan beri devam ediyordu. 1980'de bazı alanlar dışında bu tür kurslar kapatıldı. 1983'de Council for the Accreditation of Teacher Education (CATE) kuruldu ve öğretmen yetiştirme sisteminde yeni akreditasyon kriterleri kondu.

1990'ların ortalarında öğretmen yetiştirme ile ilgili düzenlemeler yapacak ve standartlar koyacak Teacher Development Agency (TDA), The Teacher Training Agency (TTA), Office for Standards in Education(OFSTED) ve Council for the Accreditation of Teacher Education (CATE) gibi kuruluşlar kuruldu.

Amerika'da 1820'lerde kadın öğretmenler akademilerde (ortaöğretim düzeyinde), erkek öğretmenler üniversitelerde yetiştiriliyordu. 1823'te Samuel R. Hall tarafından lise mezunlarının alındığ 1 ilk özel öğretmen okulu kuruldu. Henry Barnard ve Horace Mann'ın Amerika'da eğitimi ve okulları yaygınlaştırma çalışmalarına paralel olarak hem öğretmen okulu hem de üniversitede öğretmen yetiştirme çalışmaları arttı. İlk resmi öğretmen okulu H. Mann tarafından ise 1837'de Massachusetts'te kuruldu. Büyük şehirlerin lise düzeyinde kendi öğretmen okulları vardı (Labaree, 2008). Öyle ki 19.yüzyılın sonunda 127 devlet destekli öğretmen okulu ve çok sayıda özel öğretmen okulu kurulmuştu (Angus, 2001; Ogren, 2005).

Amerika'da öğretmenlerin bir sinavla seçilmeye başlamaları 1834'te Pennsylvania'da başladı (Liang, 2011). 19.yüzyıl ortalarında diğer eyaletlerde de seçmeler sınavla yapılmaya başlandı. Zamanla sınav yapılan ders alanlarının sayısı arttı. 1930'larda Amerikan Eğitim Bakanlığı (American Council on Education) Milli Öğretmen Seçme Sınavları Merkezini (National Teachers' Examination) kurdu.

1873'de Iowa'dan başlamak üzere üniversitelerde pedagoji (veya eğitim) bölümleri açılmaya başlandı ve bunlar zamanla eğitim fakültelerine dönüştü (Clifford \& Guthrie, 1988) (tabi buralarda sadece ilkokul öğretmeni değil, eğitim bilimci ve 
yöneticiler de yetiştirildi). Lisans düzeyinde öğretmen yetiştirme ise Amerika'da 1887'de New York Üniversitesi ve bir y1l sonra da Columbia Üniversitesi Teachers College'de başladı. Böylece öğretmenliğin bir meslek hâline gelme yolu açılmış oldu. 20.yüzyıl başlarında da meslek olarak sertifika standartları belirlendi. Ancak her eyalet farklı standartlar belirliyordu. 1930'larda American Council on Education ulusal öğretmen sınavları yapmaya başladı ancak sık sık ortaya çıkan öğretmen açı̆̆ı bu uygulamaları bazen zorlaştırdı.

Amerika'da dört yıllık öğretmen okulları (normal school) daha sonra yükseköğretim düzeyinde öğretmen kolejlerine (teachers college) dönüştü. 1911-1930 arasında 88 öğretmen okulu bu dönüşümü yapmıştı (Tyack,1967). 1950-1970 arasında da bütün öğretmen okulları devlet üniversiteleri bünyesinde bu dönüşümü tamamladı. Yani Amerikan öğretmen okullarının hepsi 20.yüzyıl ortalarında üniversiteleşti, öğretmen okulundan eğitim fakültesine dönüştü (became universities). Öğretmenlerin üniversitelerde yetiştirilmesinde iki farklı mekanizma ortaya çıktı: bazı öğretmen okulları üniversitelere eklendi ve orada evrimleşti (evolution into a university; Millersville, Mankato ve Montclair gibi), bazı üniversiteler de kendi kurdukları eğitim bölümlerini öğretmen okullarına ve eğitim fakültelerine dönüştürdüler (evolution within a university; Harvard, Michigan ve Berkeley gibi). Ama bir taraftan da bazı büyük üniversiteler eğitim fakültelerini kapatmaya başladılar. 1950'de Yale ve Johns Hopkins, 1980'de Duke, 1990'da Chicago, daha sonraları Michigan, Stanford (Labaree, 2008) bu üniversitelere örnek verilebilir.

1940’lara kadar öğretmen okulları dört yıllık resmi öğretmen okulları hâline geldi ve 1960-70'lerdeki yükseköğretim patlaması sırasında da hepsi üniversitelerde dört yıllık lisans programları hâline geldi. Devlet üniversiteleri bir taraftan lisans düzeyinde ilköğretim öğretmeni ve yüksek lisans düzeyinde ortaöğretim öğretmeni yetiştirmeye başladılar.

Federal yapısına rağmen Amerika, bir meslek olarak öğretmen standartları konusunda dünyada ilk çalışmaları yapan ülkelerin başında gelir. Ancak her eyalet farklı standartlar belirlediği için, sürekli yeni sertifikalandırma yöntemlerinin denendiği görülmüştür. 2000'li yıllarda ülke çapında 1350'den fazla yükseköğretim okulunda öğretmen yetiştiriliyordu ve bunlardan ancak üçte ikisi bir akreditasyon kurumu tarafından akredite edilmişti (Feistritzer, 1999) National Board for Professional Teaching Standards (NBPTS), the National Council for Accreditation of Teacher Education (NCATE) gibi kurumlar eyaletler üstü öğretmen standartları belirlediler. Teach for America ve CalTeach gibi kaliteli öğretmen yetiştirme programları uyguladilar.

Amerika'da 2008'de National Center for Education Statistics (NCES) gelecekte yüz binlerce öğretmene ihtiyaç olacağı tahminlerini yaptı (Roth \& Swail, 2000). Öte yandan uluslararası eğitim başarısı sınavlarında Amerikalı öğrencilerin oldukça geri sıralarda yer alması da bu ülkedeki öğretmen kalitesinin sorgulanmasını gündeme getirdi. 


\section{Lise Öğretmenliği}

Ortaçağlarda Avrupa'da kurulan üniversitelerin Sanat Fakülteleri genelde iki yıllık eğitim veriyorlar; bir taraftan öğrencileri tıp, hukuk, ilahiyat gibi fakültelere hazırlıyorlar bir taraftan da liselere öğretmen yetiştiriyorlardı.

Almanya'nın Protestan bölgelerinde 18.yüzyılda yeni öğretmen okulları kuruldu. Fr. A.Wolf, 1787'de Halle'de philological seminarium'u kurdu (Rausch, 1905). Wolf kurduğu öğretmen okulunda da sadece filolojiye önem vermişti.

Lise öğretmenleri sınavla seçiliyordu. Ortaöğretim okullarına öğretmen seçme sınavlarının tarihi 16. yüzyıla kadar gider. Sınavla seçmenin yanında filolojik seminerlerde 1770'li yıllardan beri lise öğretmeni de yetiştiriliyordu. Francke, Melanchton gibi bu alanda gelenek oluşturmuş eğitimciler de vardı.

Prusya'da 19. yüzyıl başında filolog öğretmenler yetiştirilmeye başlandı. Yüksek burjuva sınıfından "yüksek" gimnazyum öğretmenlerinin oğulları askerlikten muaf idi (1792; 1810'daki bir fermanla bu haklar yenilendi, 1819'da gimnazyumdaki tüm öğretmenlere verildi). 19. yüzyıl başında üniversite eğitimi pek gelişmedi ama öğretmen yetiştirmeye özel bir önem verildi. O zamanki esas öğretmenlik dil öğretmenliği olduğu için, 1825 'ten önce Almanya'da hemen her üniversitede Filoloji Seminerleri kuruldu. Ayrıca, gimnazyum öğretmeni yetiştirmek için Pedagoji seminerleri kuruldu.

Fr. A. Wolf ve Fr. Gedike'nin ön çalışmalarına göre 1809'da Bavyera'da, 1810 'da Prusya'da lise öğretmenlerini seçmek için devlet sınavları yapılmaya başlandı. Bunda Fransız yenilgisi ve Yeni hümanist felsefenin etkisi vardı. Yukarıdan yapılan bir devrimle genel eğitim ve hak eşitliği sağlanmaya çalışıldı. Eskiden Latin ve bilgin okullarında kilise görevlileri ders veriyordu. Bu reformla öğretmenlik kilise görevi olmaktan çıkarılıyordu. Almanya'da öğretmenliğin din adamlarının ikinci mesleği olmaktan çıkarılmasından sonra, 1780-1830 arasında lise seviyesinde ciddi bir öğretmen açığı ortaya çıktı ama 1830'dan 1850 başlarına kadar bir filolog öğretmen fazlalığ1 görüldü (Titze, 1991).

1810 öğretmen seçme yönetmeliğinde lise öğretmenlerinin lisans mezunlar1 arasından seçilmeleri ve öğretmenlik mesleğinin dini mesleklerden ayrılması kabul edildi. Filoloji, tarih ve matematik dallarından sinav yapılıyor ve tüm derslerin öğretmeni (Gesamtlehrer) (Jeismann, 1999) sayılıyordu. 1810'da devlet öğretmenleri sınavla seçmeye başlasa da parasını dini gruplar verdiği için öğretmenler onlara bağlı kald1. 1810'da gimnazyum öğretmenleri seçme sınavlarında (Examen pro facultate docendi) filologlar teologlardan ayrıldı. Bu sınavın çok yüksek bir saygınlığı oldu, bir efsane oldu. Humboldt, öğretmenlik sinavları vasitasıyla hem gimnazyum öğretiminin denetleneceğini hem de bir standarda kavuşacağını savunuyordu (Tenorth, 1987: 255).

1826 'da bir yıl ücretsiz staj (Probejahr) yapma uygulaması başladı. "Pro loco" öğretmenliğe giriş sınavları, "pro ascensione” belli derslerin öğretmenliğine yükselme sinavı ve "pro rectoratu”da okul müdürlüğü sinavları idi. 1831 düzenlemesi ile toplu öğretmen (Gesamtlehrer) ve genel eğitim daha da güçlendirildi ama öğretmenlerin belli derslerde uzmanlaşmasına da izin verdi. Öğretmen bütün temel derslerin öğretmeni olacağı için hem sınav hem de din işleri zordu; bu nedenle din adamları bu hizmetten 
çekildi. 1831 düzenlemesinde, ortaöğretimde öğretmenlik yapmak isteyen kim olursa olsun felsefe, pedagoji ve ilahiyattan sınava girecekti (Russel, 1899). Üç alanda öğretmen alınacaktı: a) Yunanca, Latince, Almanca; b) matematik ve fen bilimleri, c) tarih ve coğrafya. Öğretmenin ortaöğretimin alt, orta veya yüksek seviyesinde ders vereceği belirlenecekti. Prusya'nın öğretmen alımı ve yetiştirmesindeki bu yaptıkları diğer Alman devletleri tarafından da taklit edildi.

1860 'tan sonra belli derslerde uzmanlaşmış öğretmen ihtiyacı iyice kendini gösterdi ve 1866 öğretmenlik sınavı düzenlemesinde bu durum göz önüne alındı. Öğretmenlik sınavı dört ağırlıklı dalda yapılacaktı: tarih-filoloji dalı, matematik-fen bilimleri dalı, din ve İbranice dalı ve yeni diller dalı (Müller-Benedict, 2009). Birinci sınıf belge alan öğretmenler gimnazyumların bütün kademelerinde, ikinci sınıf belge alanlar alan derslerinde açık varsa ve üçüncü sınıf belge alanlar genel eğitim derslerinde (din, tarih, felsefe, pedagoji) öğretmen yetişmezse öğretmenlik yapabilecekti.

1887 öğretmenlik sınavı düzenlemesi temel alan ve yan alan (Haupt- und Nebenfächern) düzenlemesi yaptı. Öğretmenlik alanları da dil ve tarih, matematik ve fen bilimleri ile Hristiyan din öğretmenliği oldu. Öğretmenlik de Oberlehrer (her sinıfta derse girer) ve Lehrer (alt sinıflarda derse girer) olarak iki kademe yapıldı.

1890 'da staj uygulaması yeniden düzenlendi. Bir teorik eğitim bilimi gördükten sonra bir yıl deneme öğretmenliği yapacak ve öğretmen olmasına vilayet eğitim yönetimleri karar verecekti. 1898'de öğretmenlik sınavları bir daha düzenlendi ve alanlar altı dal olarak (Din-İbranice, Latince-Yunanca, Fransızca-İngilizce, MatematikFizik, Kimya ve Doğa Bilimleri, Almanca-Tarih-Coğrafya) yeniden belirlendi. Her aday üç dalda başarı gösterecekti. Başlangıçta sadece filologlar öğretmen yetiştirmeye yönelik düzenlemeler yapıyordu. 1890'dan itibaren üniversiteler öğretmen yeterliklerini kazandıran bir öğretim dönemi düzenlemeye başladılar.

Fransa'da 1989 Jospin Yasası, öğretmen yetiştirme sistemini değiştirdi ve üniversitelerde Öğretmen Yetiştirme Enstitüleri (Instituts Universitaires de Formation des Maîtres, IUFM) kuruldu (Corbett, 1996). İlköğretim ve ortaöğretim öğretmenleri buralardan yetiştirilecekti. İlkokul öğretmenleri 3, lise öğretmenleri 4-5 y1l eğitim alıyor. Ortaöğretim öğretmenleri, üniversitelerdeki Öğretmen Eğitimi Enstitüleri (Instituts Universitaires de Formation des Maîtres [IUFM]) tarafindan hazırlanan bir sınavla seçiliyor. Bunlar da daha sonra Millî Eğitim Bakanlığının yaptığı bir öğretmen seçme sınavina (Certificat d'aptitude au professorat de l'enseignement du second degré (CAPES) tabi tutuluyor. 110 değişik alana öğretmen seçilir. Teknik alanda da 40 tür öğretmenlik için sınav yapılır. Meslek liseleri için aynı durum söz konusudur. IUFM sistemi 1990'da kuruldu ve şu anda 30'u aşkın enstitü var. Lisans mezunları (Bachelors) bu Enstitülere girip bir y1l eğitimden ondan sonra atama sinavlarına girmekte, kazananlar Enstitülerde bir yıl daha eğitim görmektedir (Tchibozo, 2005). 


\section{Tartışma ve Sonuç}

Öğretmenliğin meslek haline gelmesi 18. yüzyıldan 19. yüzyıla uzanan bir süreçte gerçekleşti. Meslek; bilimsel bilgilere dayall, objektif, rasyonel, etkili bir faaliyet haline geldi. Metot öğretildi. Kerschensteiner Eğiticilerin Ruhu'nu, Spranger Doğuştan Eğitici'yi yazdı. Öğretmen kişiliği ve öğretmen davranışları bu yüzyıllarda uzun uzun tartışıldı. Öğretmenleri devlet hizmetine alınması, öğretmenlerin hangi okullarda yetiştirilmesi, eğitimin program içerikleri gibi, çoğu 20. yüzyılda tartışılan ve gerçekleştirilmeye çalışılan fikirler gündeme getirildi. Diesterweg, Kapp, Hintze, Wander, Dörpfeld, Roßmäßler, Thaulow gibi birçok eğitimci bu tartışmaları yaptı. Öğretmen dernekleri birçok toplantı yapıp öneriler sundular (Tenorth, 2000). 1848 devrimi sırasında öğretmen eğitiminin üniversite düzeyinde yapılması istendi, ama Diesterweg gibi eğitimciler bunu reddettiler; üniversitenin mesleki becerileri kazandıramayacağını düşündüler.

Modern eğitim sistemleri farklı zamanlarda farklı biçimlerde doğdu. Modern kapitalist devlet sisteminin doğuşu ve biçim kazanması belki en çok eğitim alanında ve eğitim vasıtasıyla gerçekleştirildi. Okullar sosyal değişmenin ve biçimlendirmenin aracı oldu. Aydınlanma dönemimden başlayan, 19 ve 20. yüzyıllarda sistematikleşen ulus devletlerin oluşumunda eğitim Avrupa, Amerika, Asya ülkelerinde bir vasita olarak kullanıldı (Kazamias, 2009; Green, 1990). Vatandaşlık, sosyal dayanışma, milli kimlik, milli kültür, demokrasi kavramlarının yerleştirilmesi ve modern devlet bürokrasisinin yerleştirilmesinde eğitim önemli bir rol oynadı. Aydınlanma döneminde anayasalcılık, cumhuriyetçilik, demokrasi, vatandaş, ilerleme, akılcılık, özgürlük / hürriyet, laiklik, milliyetçilik, ulus-devlet, kilise ve devlet ayrılığı ve bir ulusal kamu / devlet sistemi kavramları eğitim vasıtasıyla yerleştirildi (Harvey, 1990). Amerika'da egemen ideolojinin ve sosyal düzenin yerleştirilmesinde eğitim esaslı bir rol oynadı. Devletler okulların kurulmasından ziyade programı, yönetimi ve kontrolünde etkin rol aldılar. Bu arada biçimlendirme kadar tüm ülke çapındaki eğitimi bütünleştirme rolü de oynadılar (Grew \& Harrigan, 1992). 19.yüzyılda eğiten devlet (educating state) demokratikleşmede ve sosyal politikada anahtar rol oynadı (Swaan,1988). Ulus devlet dini farklılıkları, bölgeciliği, feodalizmi, göçmen ve azınlıkları kaldırdı; toplumsal bütünleşmeyi sağladı, ekonomik kalkınmada önemli rol oynadı. Kitle eğitimi ve standart müfredat uygulanmaya başlandı. Herkesin kendi zekâ, yetenek ve çalışmasına göre toplumda adil bir yer almasını (meritocratic distribution) sağlad1. 19.yüzyıl sonlarında anayasal devletlerde sosyal bir hak olan eğitim, 20.yüzyılda insan sermayesi olarak görülmeye başlandı. Eğitimin ulus oluşturma, ekonomik refahı artırma, demokratik hayatı geliştirme gibi hususlarda etkisi görüldükçe, sistemin yürütücü gücü olan öğretmenlerin eğitimine daha çok önem verildi.

Amerikan üniversitelerinde eğitim bilimleri bölümlerinin kurulması, psikoloji alanında gelişim, zekâ ve öğrenme teorileri konularındaki gelişmeler öğretmen yetiştirmede yeni ufuklar açtı.

Öğretmen okulu mezunu öğretmenler zamanla saygınlık kazandı. Öğretmenliğin din adamlarının yan görevleri olmaktan çıkartılıp belli sınavlarla seçilmesi, dil 
öğretmenlerinin yanında alan öğretmenlerinin de yetiştirilmesi, alan eğitimi yanında bir de pedagoji eğitimi ve pratiği verilmesi de yaklaşık bir 100 yıllık zaman aldı.

Önceleri gimnazyum öğretmenleri üniversitede sadece alan eğitimi görüyorlardı. 1890'dan itibaren öğretmen yetiştirmede eğitim bilimleri de devreye girdi ve iki kademeli öğretmen yetiştirme faaliyetleri başladı. Ama bu iki safhanın üniversitelerde birleştirilmesi ve bütünleştirilmesi zaman aldı. Üniversitenin bu yeni göreve, öğretmen yetiştirmenin bu yeni çevreye uyumu kolay olmadı. Bilim mi önemli, meslek mi tartışması 30-40 yıl devam etti.

Daha sonra öğretmen yetiştirme politikası gene birçok açılardan tartışılmaya devam etti. Şu fikir çok tartışıldı ve hâlâ da tartışılıyor: Üniversiteler, öğretmen yetiştirme için iyi yerler değildir. Üniversiteler iyi öğretmen yetiştiremiyor; örneğin lise öğretmenleri. Önlerindeki üniversite öğretim elemanları iyi öğretmen örneği değildir. Orta çağlardan beri üniversite öğretmenleri öğrencilerinin öğrenmesine önem vermeyen, öğrencilere yabancı kişilerdir. Büyük Alman öğretmen eğitimcisi Diesterweg, daha 1836'da bunun böyle olduğunu söylüyordu (Tenorth, 2012).

Öğretmen eğitiminin akademikleşmesinin ortaya çıkardığı sorunlar daha önce de tartış1ld1. Hamburg ve Leipzig'de öğretmen eğitimi 1920'lerde üniversitelere bırakılmıştı. Hamburg'da William Stern ve öğrencileri Martha Muchow ve Gustav Deuchler gibi eğitimciler çalıştı. Leipzig'de üniversite ve öğretmenler derneği birlikte çalıştı. Hamburg uygulamalarını eleştiren Georg Geißler, üniversitenin teori-uygulama sorununu çözemediğini söylüyor, Öğretmen Okullarının Intikamı (Rache des Lehrerseminares) diye bir yazı yazıyordu. Üniversiteler uygulamadan uzak yerlerdi. Ona göre teori ve pratik bütünleştirilmeli, daha doğrusu teori pratiğin hizmetinde olmalıydı (Tenorth, 2012).

Eğitim bilimlerinin içinde öğretim tekniği ve diğer yönleri geliştirmek ve bir öğretmen eğitimi yapmak gerekir. Eğitim Fakülteleri bir alan eğitimcisi ve bir eğitim bilimci tarafından ortaklaşa yönetilmelidir. Üniversiteye bağlı akademi iki sütun üzerinde yükselmelidir: öğretim ve araştırma. Üniversitelerde eğitim ve alan eğitimi araştırmaları ile öğretmen eğitiminin iç içe gitmesi gerektiği hala tam anlaşılamamıştır. $\mathrm{Bu}$ iki sütunu birbirine bağlayan nedir? Programlardaki hangi derslerin öğretmenlik mesleği ile alakaları nedir? Akademik programlar derken uygulamadan da iyice uzaklaşılmamalıdır.

Her zaman tartışılan şu oldu: Bilim mi, meslek mi? (Theorie-Praxis-Problem). Program mutlaka mesleğe hazırlamalıdır. Humboldt'un "Einheit von Forschung und Lehre” ilkesi tam burada uygulanmalıdır.

20 yüzyılın bir başka özelliği ilköğretim alanında öğretmenlik mesleğinin kadınlaşması (Feminisierung des Lehrerberufs) olgusunun giderek artmasıdır (Herrlitz vd. (Eds), 2009). Hatta bu olgu günümüzde pedagojik sonuçları itibarıyla tartışılmaya başlanmıştır. 


\section{Kaynakça}

Alexander, T. (1919). The Prussian elementary schools. New York, NY: The Macmillan Company. Retrieved from http://archive.org/details/prussianelement00alexgoog

Altekar A. S. (1948). Education in ancient India, Benaras. Retrieved from http://www.archive.org/stream/educationinancie032398mbp/educationinancie03239 8mbp_djvu.txt

Angus, D. L. (2001). Professionalism and the public good: A brief history of teacher certification. Washington, DC: Thomas B. Fordham Foundation. Retrieved from http://files.eric.ed.gov/fulltext/ED449149.pdf

Atay, H. (1981). Fatih-Süleymaniye medreseleri ders programları ve icazet-nâmeler. Vakıflar Dergisi, 13, 171-235.

Ayar, T. (2014). Bir Osmanlı müderrisinin icâzetnâmesi ve tarihî kaynak değeri üzerine baz1 mülahazalar. Turkish Studies, 9(1), 43-62. Retrieved from http://www.turkishstudies.net/Makaleler/780147016_04AyarTalip-trh-43-62.pdf

Aytaç, K. (2012). Avrupa ĕgitim tarihi. İstanbul: Phoenix Yayınevi.

Barnard, H. C. (1969). Education and the French revolution. Cambridge: Cambridge University Press. Retrieved from http://books.google.com.tr/books?id=jfI8AAAAIAAJ

Bettermann, K. A. \& Goessl, M. (1963). Schulgliederung, lehrerbildung und lehrerbesoldung in der bundesstaatlichen ordnung. Berlin: Duncker \& Humblot. Retrieved from http://books.google.com.tr/books?id=aA3OzlRA-RoC

Blömeke, S. (2009). Lehrerausbildung. In Blömeke, S., Bohl, Th., Haag, L., LangWojtasik, G. \& Sacher, W. (Eds.), Handbuch schule. Theorie-organisationentwicklung (pp. 483-490). Bad Heilbrunn/Stuttgart: Klinkhardt/UTB. Retrieved from http://www.erziehungswissenschaften.huberlin.de/institut/abteilungen/didaktik/data/aufsaetze/bloemekelehrerausbildung.pdf

Cabanel, P., \& Encrevé, A. (2006). De Luther à la loi Debré: protestantisme, école et laïcité. Histoire de l'Education, 110, 5-21. Retrieved from http://histoireeducation.revues.org/index1341.html

Cai, Z. (2002). Configurations of comparative poetics: Three perspectives on Western and Chinese literary criticism. Hawai: University of Hawaii Press. Retrieved from https://books.google.com.tr/books?id=Zk2yr9GnowwC

Clifford, G.J., \& Guthrie, J.W. (1988). Ed school: A brief for professional education. Chicago: University of Chicago Press.

Compayré, G. (1889). The history of pedagogy (Trans.W.H.Payne). Boston: D. C. Heath \& Company. Retrieved from http://archive.org/details/historyofpedagog00compuoft 
Cong, X. (2007). Teachers' schools and the making of the modern Chinese nation-state, 1897-1937. Vancouver: UBC Press.

Corbett, A. \& Moon, B. (1996). Education in France: Continuity and change in the mitterrand years 1981-1995. New York: Routledge. Retrieved from http://books.google.com.tr/books?id=SM2P2q_wpSwC

Cortis, G. (1985). The closure and re-organisation of institutions of teacher education in England and Wales, 1972-1981. The Journal of Educational Thought, 19(1), 13-23.

Curtis, S.A. (1994). Educating the faithful: Catholic primary schooling and the teaching congregations in the diocese of Lyon, 1830-1905 (Unpublished dissertation) Indiana University.

Dent, H C. (1977) The training of teachers in England and Wales, 1800-1975. London: Hodder and Staughton

Ding, G. (2001). Nationalization and internationalization: Two turning points in China's education in the twentieth century. In Peterson, G., Hayhoe, R., \& Lu,Y. L. (Eds), Education, Culture, and Identity in Twentieth-Century China (pp. 161-186). Hong Kong: Hong Kong University Press.

Donnermair, C. (2010). Die staatliche Übernahme des Primarschulwesens im 19. Jahrhundert: Maßnahmen und Intentionen. Vergleich Frankreich - Österreich (Unpublished Dissertation). Wien Ünivertität. Retrieved from http://othes.univie.ac.at/9306/1/2010-03-02_7301195.pdf

Duncan, R. (2013). Man, know thyself: Volume 1 corrective knowledge of our notable ancestors. Xlibris Corporation.

Ehret, H. (1971). L'Ecole Normale d'Instituteurs du Haut-Rhin a Colmar (1832-1850). Paris: Presses Univ. Franche-Comté. Retrieved from http://books.google.com.tr/books?id=-iQV_Er-bzkC

Elman, B.A. (2000). A cultural history of civil service examinations in late imperial China. Berkeley, Los Angeles \& London: University of California Press.

Ergün, M. (1996). Ders Programları Ve Ders Kitapları Tarihi - I, Medreselerde Okutulan Dersler ve Ders Kitapları. A.K. ̈̈. Anadolu Dil-Tarih ve Kültür Araştırmaları Dergisi, 1, 1-16. Retrieved from www.egitim.aku.edu.tr/moders.htm

Ergün, M. (2014). Suriye, Misır ve Anadolu Medreseleri (15.yüzyll ortalarına kadar), Ankara: Pegem Yayınları.

Fosseyeux, M. (1912). Les écoles de charité à Paris sous l'ancien régime et dans la première partie $d u$ XIX siècle, Paris: Nougent le-Rotrou. Retrieved from http://archive.org/details/lescolesdechar00fossuoft

Feistritzer, C. E. (1999). The making of a teacher: A report on teacher preparation in the U.S..Washington, DC: National Center for Education Information.

Gaus, D. \& Drieschner, E. (2010). 'Bildung' jenseits pädagogischer Theoriebildung?: Fragen zu Sinn, Zweck und Funktion der Allgemeinen Pädagogik, Springer-Verlag. Retrieved from https://books.google.com.tr/books?id=qc4Cf32PwBoC 
Gemie, S. (1995). Women and schooling in France, 1815-1914: Gender, authority and identity in the female schooling sector. Edinburgh: Edinburgh University Press. Retrieved from http://www.google.com.tr/books?id=QaMIrsT8ck0C

Green, A. (1990). Education and state formation: The rise of education systems in England, France and the USA. New York: St. Martin's Press.

Grew, R. \& Harrigan, P. J. (1992). School, state, and society: The growth of elementary schooling in nineteenth-century France: A quantitative analysis. Ann Arbor: The University of Michigan Press.

Harrigan, P. J. (2001). Church, state, and education in France from the Falloux to the Ferry Laws: A reassessment. Canadian Journal of History, April. Retrieved from http://utpjournalsreview.com/index.php/CJOH/article/view/10994/9869

Harvey, D. (1990). The condition of postmodernity: An enquiry into the origins of cultural change. Oxford: Blackwell

Herrlitz, H.-G., Titze, H., Hopf, W., \& Cloer, H. (2009). Deutsche Schulgeschichte von 1800 bis zur Gegenwart: Eine Einführung. Beltz Juventa. Retrieved from http://books.google.com.tr/books?id=8XfsPZ4wH_8C

Hüttner, D. (1982). Von der normalschule zum lehrerseminar. die entstehung der seminaristischen lehrerbildung in Bayern (1770 -1825). München. Retrieved from http://www.utzverlag.de/buecher/46118dbl.pdf

James, G. M. (1954). Stolen Legacy: Greek philosophy is stolen Egyptian philosophy. New York: Philosophical Library. Retrieved from http://www.jpanafrican.com/ebooks/eBook\%20Stolen\%20Legacy.pdf

Jeismann, K.-E. (1977). Die stielschen regulative. In Herrmann, U. (Eds.), Schule und Gesellschaft im 19. Jahrhundert (pp. 137-161). Weinheim.

Jeismann, K.-E. (1987). Zur Bedeutung der 'Bildung' im 19. Jahrhundert. In Jeismann, K.-E. \& Lundgreen, P. (Eds.), Handbuch der deutschen Bildungsgeschichte, Bd. 3: Von der Neuordnung Deutschlands bis zur Gründung des Deutschen Reiches 18001870 (pp. 1-21). München.

Jeismann, K.-E. (1999). Zur Professionalisierung der Gymnsiallehrer im 19. Jahrhundert. In H.-J. Apel et al. (Eds.), Professionalisierung pädagogischer Berufe im historischen Prozess (pp. 59-79). Bad Heilbrunn.

Jeong, U. Y. (2009). Teacher policy in England: A historical study of responses to changing ideological and socio-economic contexts (Unpublished Doctoral Dissertation). Bath University. Retrieved from http://opus.bath.ac.uk/18560/1/TEACHER_POLICY_IN_ENGLAND_(UN_YON G_JEONG).pdf

Kaestle, C. (1973). Joseph Lancaster and the Monitorial School Movement. New York/London: Teachers College Press 
Kazamias, A. M. (2009), Modernity, state-formation, nation building, and education in Greece, In Cowen, R., Kazamias, A. M. (Eds.) International handbook of comparative education (pp. 239-256). Netherlands: Springer Netherlands.

Kiriş-Yılmaz, N. (2012). Sofistler 'Sofist' miydi? SDÜ Fen Edebiyat Fakültesi Sosyal Bilimler Dergisi, 25, 163-178. http://sablon.sdu.edu.tr/dergi/sosbilder/dosyalar/25/25_11.pdf adresinden alınmıştır.

Koch, R. (1989). Vocational education in France - Structural problems and present efforts toward reform, CEDEFOP document. Retrieved from http://www.eric.ed.gov/PDFS/ED360495.pdf

Köymen, M. A. (1975). Alp Arslan zamanı Selçuklu kültür müesseseleri. Selçuklu Araştırmaları Dergisi, 4, 75-124

Kramer, S. N. (1963). The Sumerians: Their history, culture and character. University of Chicago Press, $1963 . \quad$ Retrieved from http://people.ucls.uchicago.edu/ cjuriss/ModernWorld/Documents/Jurisson-UNIT2-Kramer-The-Sumerians-Education.pdf

Labaree, D. (2008). An uneasy relationship: The history of teacher education in the university. In M. Cochran-Smith, S. Feiman-Nemser, \& J. McIntyre (with K. Demers) (Eds.), Handbook of research on teacher education (3rd ed.) (pp. 290306). New York: Routledge. Retrieved from https://web.stanford.edu/ dlabaree/publications/An_Uneasy_Relationship_Proofs.p df

Lee, T. (2000). Education in traditional China: A history. Leiden, Boston \& Köln: Brill.

Lewis, H. D. (1985). The French education system. New York: St. Martin's Press.

Liang, S. (2011), Teaching and teacher education in the US: What does the literature tell us?. Presented at 5th Annual International Conference on Mathematics, Statistics \& Mathematical Education, 13-16 June 2011, Athens, Orphanos.

Meyer, C. (2003). Friedrich Eberhard von Rochow's education of the children in rural communities and its impact on urban educational reforms in the eighteenth century. Paedagogica Historica: International Journal of the History of Education, 39(1-2), 19-35.

Retrieved

from http://www.tandfonline.com/doi/abs/10.1080/00309230307461

Müller-Benedict, V. (2009). Das höhere Lehramt. In Titze, H. \& Müller-Benedict, V. (Eds.), Datenhandbuch zur deutschen Bildungsgeschichte (pp. 187-220) $\begin{array}{lllll}\text { Vandenhoeck \& } & \text { Ruprecht. } & \text { Retrieved }\end{array}$ http://books.google.com.tr/books?id=2p7ZYzRjp-QC

Neugebauer, W. (1985). Absolutistischer Staat und Schulwirklichkeit in BrandenburgPreussen, Berlin: Walter de Gruyter. Retrieved from http://books.google.com.tr/books?id=c8phWEMSJEsC

Nuaymî, (1990). ed-Dâris fî Târîhu'l-Medâris. Beyrut: Darü'l-Kütübü'l-İlmiye, Retrieved from http://ia700407.us.archive.org/3/items/waq9737/02_9738.pdf http://www.almeshkat.net/books/archive/books/mdarees.zip 
Ofenbach, B. (2006). Geschichte des pädagogischen Berufsethos: Realbedingungen für Lehrerhandeln von der Antike bis zum 21. Jahrhundert. Würzburg: Königshausen \& Neumann. Retrieved from http://www.google.com.tr/books?id=_vOS3uJmtrwC

Ogren, Ch. (2005). The American state normal school: "An instrument of great good." New York: Palgrave Macmillan.

Özgül, O. (2011). Sümer sosyal hayatında eğitimin yeri ve önemi. Erzincan Üniversitesi Sosyal Bilimler Dergisi, 4(2), 401-414. Retrieved from http://dergipark.ulakbim.gov.tr/erzisosbil/article/download/5000045637/500004299 2

Parker, S. C. (1912). A Textbook in the history of modern elementary education. Boston: Ginn and Company. Retrieved from http://archive.org/details/atextbookinhist01parkgoog

Prost, A. (1968). Histoire de l'enseignement en France, 1800-1967. Paris. Retrieved from http://books.google.com.tr/books?id=U_KTOwAACAAJ

Prost, A. (1981). Histoire générale de l'enseignement et de l'éducation en France, $t$. IV, L'école et la famille dans une société en mutation (depuis 1930). Paris: Nouvelle Librairie de France.

Rausch, E. (1905). Geschichte der Pädagogik und des gelehrten Unterrichts im abrisse dargestellt. Leipzig: A. Deichert. Retrieved from http://archive.org/stream/geschichtederp00raus

Reyer, J. (2006). Einführung in die Geschichte des Kindergartens und der Grundschule. Julius: Klinkhardt. Retrieved from http://books.google.com.tr/books?id=zqI5RkTJVUQC

Robinson, W. (2003). Pupil teachers and their professional training in pupil-teacher centres in England and Wales, 1870-1914. Lewiston: The Edwin Mellen Press.

Robinson, W. (2006). Teacher training in England and Wales: Past, present and future perspectives. Education Research and Perspectives, 33(2), 19-36. Retrieved from http://www.erpjournal.net/wp-content/uploads/2012/07/ERPV33-2_Robinsn-W.2006.-Teacher-training-in-England-and-Wales.pdf

Rogers, R. (2005). From the salon to the schoolroom: Educating Bourgeois girls in nineteenth-century. France: Penn State Press. Retrieved from http://www.google.com.tr/books?id=NXFyfOUOnTUC

Roth, D., \& Swail, W. S. (2000). Certification and teacher preparation in the United States. Washington, DC: Educational Policy Institute. Retrieved from http://www.educationalpolicy.org/pdf/prel\%20certification.pdf

Russell, J. E. (1899). The German Higher Schools. Longmans, Green \& Co. Retrieved from http://archive.org/details/germanhigherscho00russuoft

Sayıll, A. (1991). Misirlılarda ve Mezopotamyalılarda matematik, astronomi ve tip. Ankara: TTK Yay. 
Scharfe, H. (2002). Education in ancient India. Brill. Retrieved from http://books.google.com.tr/books?id=7s19sZFRxCUC

Seeley, L. (1904). History of education. New York: American Book Company. Retrieved from https://archive.org/details/historyofeducati034967mbp

Skopp, D.R. (1982). The Elementary school teachers in "Revolt": Reform proposals for Germany's Volksschulen in 1848 and 1849. History of Education Quarterly, 22(3), 341-361. Retrieved from http://www.jstor.org/stable/367773

Starr, D. (2012). China and the Confucian Education Model. Universitas 21. Retrieved from www.universitas21.com/.../Download/300

Swami, S. (1995). Hindu Dharma. The universal way of life. Chennai. Retrieved from http://www.gyanbhakti.com/downloads/hindudharma.pdf

Swaan, A.de (1988). In care of the state. health care, education and welfare in Europe and the USA in the modern era. New York: Oxford University Press

Tchibozo, G. (2005). Performance management in the French system of secondaryteacher training. International Review of Education, 51(1), 3-21. Retrieved from http://www.jstor.org/stable/25054498

Tenorth, H.E. (1987). Lehrerberuf und Lehrerbildung. In Jeismann, K.-E. \& Lundgreen, P. (Eds.), Handbuch der deutschen Bildungsgeschichte. Bd.3. 1870-1918 (pp. 250270). Von der Reichsgründung bis zum Ende des Ersten Weltkrieges. München.

Tenorth, H.-E. (2000). Geschichte der Erziehung. Einführung in die Grundzüge ihrer neuzeitlichen Entwicklung. Weinheim: München. Retrieved from http://books.google.com.tr/books?id=NxwVFbuCN_oC

Tenorth, H.-E. (2012). Akademisierung der Lehrerbildung - Perspektiven eines ambivalenten Programms. Presented at Johann Wolfgang Goethe-Universität (Frankfurt am Main) in the opening ceremony of "Akademie für Bildungsforschung und Lehrerbildung“. Retrieved from http://www.abl.unifrankfurt.de/42269961/Keynote_Prof_-Dr_-Heinz-Elmar-Tenorth.pdf

Titze, H. (1991). Lehrerbildung und professionalisierung. In Berg, Ch. (Eds.), Handbuch der deutschen Bildungsgeschichte, Bd. IV: 1870-1918. München.

Travagnin, S. (2014). Concepts and institutions for a new Buddhist education: Reforming the Samgha between and within state agencies. East Asian History, 39, 89-102. Retrieved from http://www.eastasianhistory.org/sites/default/files/articlecontent/39/pdfs/EAH39-Travagnin.pdf

Tyack, D. B. (Ed.) (1967). Turning points in American educational history. Waltham, MA: Blaisdell Publishing Company.

Uçak, Ö. (2006). Felsefi farklılaşma sorulardan değil cevaplardan doğar: Sofistler ve Platon. Felsefe ve Sosyal Bilimler Dergisi, 1, 69-76. Retrieved from http://www.flsfdergisi.com/sayi1/69-76.pdf 
Wilke, F. (2005). Lehrerbildungszentren in Deutschland. In Merkens, H. (Ed.) Lehrerbildung: Zentren Für Lehrerbildung, Springer DE, 93-102. Retrieved from http://www.google.com.tr/books?id=8W4uZ1 xJQCUC

Wriedt, M. (2008). Säkularisierung wider Willen. Der säkularisierende Modernisierungsschub infolge der reformatorischen Schul- und Universitätsreform. In Jacobi, J. \& Le Cam, J.-L. (Eds.), Säkularisierung vor der Aufklärung ?: Bildung, Kirche und Religion 1500-1750 (pp. 55-76). Köln, Weimar, Wien: Böhlau. Retrieved from http://books.google.com.tr/books?id=ffnpfSwFXCEC

Wüstenfeld, F. (1837). Die Academien der Araber und ihre Lehrer: Nach Auszügen aus Ibn Schohba's Klassen der Schafeïten, Göttingen. (https://ia902306.us.archive.org/7/items/dieacademiender00gtgoog/dieacademiende r00gtgoog.pdf)

Zulu, I. M. (2012). The ancient kemetic roots of library and information science. The Journal of Pan African Studies, 5(1), 1-25. Retrieved from http://www.jpanafrican.com/edocs/e-DocAKRLIS.pdf 